Ambiente \& Água - An Interdisciplinary Journal of Applied Science
ISSN 1980-993X - doi:10.4136/1980-993X
www.ambi-agua.net
E-mail: ambi.agua@gmail.com

\title{
Background and the use of isoscapes in the Brazilian context: essential tool for isotope data interpretation and natural resource management
}

\author{
ARTICLES doi:10.4136/ambi-agua.2282
}

Received: 23 May 2018; Accepted: 01 Feb. 2019

\author{
João Paulo Sena-Souza ${ }^{1 *(\mathbb{D})}$; Fábio José Viana $\operatorname{Costa}^{2}{ }^{(D}$; Gabriela Bielefeld Nardoto ${ }^{1}$ \\ ${ }^{1}$ Universidade de Brasília (UnB), Brasília, DF, Brasil \\ Instituto de Ciências Biológicas (IB). Departamento de Ecologia. E-mail: jpsenasouza@gmail.com, \\ gbnardoto@unb.br \\ ${ }^{2}$ Instituto Nacional de Criminalística (INC), Brasília, DF, Brasil \\ Departamento de Polícia Federal. E-mail:mr.f.bio@gmail.com \\ *Corresponding author
}

\begin{abstract}
Spatial patterns of stable isotope ratios can be represented in spatial models called isoscapes, and have been widely used to track biogeochemical processes in natural and anthropic systems. Isoscapes have the potential to improve isotope dissemination and interpretation of spatial patterns, increase scientific results appropriation by non-specialists and improve natural resource management. However, the isoscape approach has not commonly been used in studies performed in the Brazilian context. Isoscapes with oxygen, hydrogen, nitrogen and carbon stable isotopes contribute in areas such as animal migration, forensics, hydrology, and studies on population, community and ecosystem level, among others. Here, we show the well-known global use and applications of isoscapes in different studies worldwide as a background to point out the potential for more Brazilian researchers to employ this approach in their studies, taking advantage of existing methods and filling spatial and methodological gaps. The incorporation of isoscapes may broaden the understanding of mechanisms and processes of major biogeochemical cycles in Brazil, assist in solving crimes, track illicit drug origins, help to detect wild animal trafficking, and increase Brazilian knowledge about the hydrological cycle and animal migration patterns in the Neotropics.
\end{abstract}

Keywords: isotopic landscape, spatial patterns, stable isotope.

\section{Isoscapes e seu uso no contexto brasileiro: ferramenta essencial para a interpretação dos dados isotópicos e a gestão dos recursos naturais}

\section{RESUMO}

Padrões de distribuição espacial de isótopos estáveis podem ser apresentados em mapas chamados de isoscapes e têm sido amplamente utilizados para rastrear processos biogeoquímicos em sistemas naturais e antrópicos. Isoscapes têm o potencial de melhorar a disseminação e interpretação dos padrões espaciais de isótopos estáveis, aumentar a apropriação de resultados científicos por não-especialistas e melhorar a gestão de recursos naturais. No entanto, a abordagem de isoscape não tem sido comumente usada em estudos realizados no Brasil. Isoscapes de isótopos estáveis de oxigênio, hidrogênio, nitrogênio e carbono contribuem em áreas como migração animal, ciência forense, estudos hidrológicos e 
ecológicos a nível de população, comunidade e ecossistema, entre outros. Aqui nós mostramos uma revisão sobre o uso e as aplicações de isoscapes em diferentes estudos em todo o mundo. Também apontamos uma forma de mais pesquisadores brasileiros empregarem essa abordagem em seus estudos, aproveitando os métodos existentes e preenchendo lacunas espaciais e metodológicas. A incorporação de isoscapes pode ampliar o entendimento dos mecanismos e processos dos ciclos biogeoquímicos no Brasil, auxiliar na resolução de crimes, tráfico de drogas ilícitas e de animais silvestres e aumentar o conhecimento brasileiro sobre o ciclo hidrológico e os padrões de migração animal nos neotrópicos.

Palavras-chave: isótopos estáveis, padrões espaciais, paisagem isotópica.

\section{INTRODUCTION}

Stable isotope ratio distribution is related to geographic space. This is a fundamental feature that has led to the emergence of many studies in this growing field of knowledge with a series of new applications in recent years. This spatial variation is related to how spatially explicit variables influence isotopic fractionation and discrimination. For example, altitude and latitude highly influence $\delta^{2} \mathrm{H}$ and $\delta^{18} \mathrm{O}$, differences in regional nitrogen cycles influence $\delta^{15} \mathrm{~N}$, and differences in the plant photosynthetic pathways $\left(\mathrm{C}_{3}\right.$ or $\left.\mathrm{C}_{4}\right)$ influence $\delta^{13} \mathrm{C}$.

Spatial patterns of stable isotope ratios have been represented in spatial models, called isoscapes (isoscapes $=$ isotopic + landscapes), which allow visualization and help both data interpretation and decision making when managing natural resources (Bowen, 2010a). Isoscapes enable the statistical filling of spatial gaps where isotope ratio information has not been represented (Bowen, 2010a). Isoscapes can be based on any of both abiotic elements, such as water (Terzer et al., 2013) and soil (Weintraub et al., 2016), as well as biotic elements, such as plant (Powell et al., 2012), animal (Vander Zanden et al., 2018) and human tissues (Valenzuela et al., 2011). For this reason, isoscapes have been used in a wide range of scientific areas, such as ecology, climate change, biogeochemistry, hydrology, forensic sciences, anthropology, and commercial regulation, among others (Bowen et al., 2009).

The effort to map stable isotope ratios in the landscape precedes the term "isoscape", which was idealized in 2006 (West et al., 2006). Before that, mathematical models were developed to map global $\delta^{15} \mathrm{~N}$ patterns in soil (Amundson et al., 2003), global $\delta^{13} \mathrm{C}$ patterns in biosphere focusing on carbon isotope discrimination during photosynthesis (Lloyd and Farquhar, 1994), and of $\delta^{18} \mathrm{O}$ in atmospheric $\mathrm{CO}_{2}$ (Farquhar et al., 1993). The $\delta^{18} \mathrm{O}$ and $\delta^{2} \mathrm{H}$ global maps were also developed, mainly based on a database with precipitation isotopic ratios provided by the Global Network for Isotopes in Precipitation (GNIP) (Bowen and Revenaugh, 2003). With improvements in mapping technologies, interpolation techniques, and transfer functions, the isoscape approach has become a fertile scientific application field (West et al., 2010).

Reviews of isoscapes (Bowen et al., 2009; Bowen, 2010a) and a book focused on isoscape concepts and techniques (West et al., 2010) have already been published. However, the present compilation is the first that presents an extensive update on isoscape application followed by indications of perspectives and future applicability in Brazil, a region recognized worldwide for its high biological diversity and landscape heterogeneity. As a country of continental size, Brazilian scientific works that use stable isotopes can adapt global isoscapes from literature to solve national scientific problems. In addition, creating new isoscapes in different spatial and temporal scales to Brazil may fill existent scientific gaps on stable isotope distribution, improving the knowledge on spatial patterns of carbon and nitrogen biogeochemical cycles, hydrological cycles, trophic niches and animal movements, and food authentication and forensics. 
In this context, we explore here the key concepts and methods used in the design of isoscapes presenting a brief explanation about stable isotope spatial distribution mechanisms, the major problems related to scale definition, and the already used methodologies to generate isoscapes. With that in mind, associated to a summary of the main applications of isoscapes in the areas of water cycle, ecosystem ecology, animal movement and forensic studies, we present how the use of isoscapes could be an essential tool for isotope data interpretation and natural resource managing in Brazil.

\section{METHODOLOGY}

We searched for publications in the Web of Science (http://thomsonreuters.com/web-ofscience) databases using the word "isoscape" or "isoscapes" as a topic (present in the abstract, keyword, or title). In order to expand the search, we explored the reference lists of the retrieved articles. We classified the articles according to the topics defined in this work: water cycle studies, ecosystem approach studies, animal movement, and forensic applications. Although there are isoscapes of several elements, we restricted the search to $\delta^{2} \mathrm{H}, \delta^{18} \mathrm{O}, \delta^{13} \mathrm{C}$ and $\delta^{15} \mathrm{~N}$ isoscapes. To present papers in which isoscapes could be used in order to show the potential use of this approach in the Brazilian context, we searched for articles using the word "stable isotopes". This search was performed on the Web of Science and Scielo databases.

To illustrate some existent isoscapes that can be used in the Brazilian context, we used isoscapes available in literature. World precipitation $\delta^{2} \mathrm{H}$ and $\delta^{18} \mathrm{O}$ isoscapes are accessible to download on http://www.waterisotopes.org in raster format, with $10 \mathrm{~km} \mathrm{x} 10 \mathrm{~km}$ spatial resolution. We used climatic data from http://www.worldclim.org to elaborate soil $\delta^{15} \mathrm{~N}$ isoscape to Brazil based in Amundson et al. (2003) equation for $0-10 \mathrm{~cm}$ depth $\left(\delta^{15} \mathrm{~N}_{\text {soil((0-10) }}\right.$ $=0.134 *$ MAT $-0.0005 *$ MAP +3.1985$)$. For $\delta^{13} \mathrm{C}$ isoscape, we used the model elaborated by Powell et al. (2012) to South America under their previous authorization.

\section{KEY CONCEPTS AND METHODS USED IN THE DESIGN OF ISOSCAPES}

\subsection{Describing stable isotopes and their natural variations}

Isotopes are atopic species of the same element. Therefore, they contain the same number of protons in the atomic nucleus, but different numbers of neutrons. The stable isotopes are those that do not emit any kind of radiation. Carbon stable isotopes, for example, are ${ }^{12} \mathrm{C}$ and ${ }^{13} \mathrm{C}$. The first one contains 6 protons and 6 neutrons in the nucleus, the second has the same number of protons, but 7 neutrons. The elements of major biogeochemical cycles that have more than one isotope (hydrogen, oxygen, carbon and nitrogen) are so called the light stable isotopes.

The natural abundance of heavier isotope atoms is significantly smaller compared to the lighter atoms. Therefore, the isotope ratio $(\mathrm{R})$ of the sample is compared to the $\mathrm{R}$ of a preset international standard to define the value of delta: $\delta=\left(R_{\text {sample }} / R_{\text {standard }}-1\right) * 1000$, where $R_{\text {sample }}$ is the ratio between heavier and lighter atoms of the sample, and $R_{\text {standard }}$ is the ratio between heavier and lighter atoms of a standard. The $R$ value is dimensionless and via criteria of provenance is less than zero. Thus, its value is multiplied by a thousand, creating a notation called $\delta$ per mil (\%o).

Biogeochemical and physical processes lead to differences in reaction between light-heavy isotopes generating different proportion of them on materials or environment. The main process that leads the carbon isotope discrimination $\left(\Delta^{13} \mathrm{C}\right)$ is photosynthesis. There are two main metabolic pathways of $\mathrm{CO}_{2}$ absorption by plants: $\mathrm{C}_{3}$ (Calvin Cycle) and $\mathrm{C}_{4}$ (Hatch-Slack Cycle). $\mathrm{C}_{3}$ plants discriminate more ${ }^{13} \mathrm{C}$ from $\mathrm{CO}_{2}$, thus have lower $\delta^{13} \mathrm{C}$, varying between -35 
$\%$ and $-20 \%$. In contrast, $\mathrm{C}_{4}$ plants have higher $\delta^{13} \mathrm{C}$ values, with variation pattern between $15 \%$ and $-11 \%$ (Powell et al., 2012). In general, $C_{3}$ plants are tree and shrub species, while $\mathrm{C}_{4}$ plants are represented by tropical grasses (e.g. corn and sugarcane). The $\delta^{13} \mathrm{C}$ isoscapes are generally elaborated through methods that differentiate plants with $\mathrm{C}_{3}$ or $\mathrm{C}_{4}$ metabolisms (Powell et al., 2012).

However, differences in carbon isotope ratio can be found in the same photosynthetic group $\left(\mathrm{C}_{3}\right.$ or $\left.\mathrm{C}_{4}\right)$ or even in multiple individuals in the same species. Those differences occur due to environmental control or genotype-specific physiological influences in carbon isotopic discrimination among plants (Cernusak et al., 2013). In $\mathrm{C}_{3}$ plants, leaf $\delta^{13} \mathrm{C}$ might decrease with increasing the ratio of intercellular to ambient $\mathrm{CO}_{2}$ concentrations $(\mathrm{ci} / \mathrm{ca})$, which is a function of $\mathrm{CO}_{2}$ supply from the atmosphere to the intercellular air spaces through stomata (Orchard $e t$ al., 2010). In addition to allowing the diffusion of $\mathrm{CO}_{2}$ in the leaf, the stoma prevents water loss. Therefore, soil water availability and atmospheric pressure also influence $\Delta^{13} \mathrm{C}$. Plant $\delta^{13} \mathrm{C}$ has a negative correlation with the transpiration efficiency and has been used to access wateruse efficiency, which can change following environmental gradients. Generally, $\Delta^{13} \mathrm{C}$ decreases with the decrease of MAP (Cernusak et al., 2013).

There is a general pattern of increasing $\delta^{13} \mathrm{C}$ value with the increase of elevation among $\mathrm{C}_{3}$ plants. In higher altitudes, the ci/ca ratio decreases with the decrease of atmospheric pressure. The lower temperature in high altitudes can increase the $\Delta^{13} \mathrm{C}$ as well. The availability of nutrients in the soil is another factor that influences the isotopic discrimination of carbon by the $\mathrm{C}_{3}$ plant due to the direct influence on photosynthetic capacity. Discrimination of the carbon isotope decreases with increasing $\mathrm{N}$ concentration in the leaf (Cernusak et al., 2013). Light availability is the main environmental condition that causes $\Delta{ }^{13} \mathrm{C}$ variation among $\mathrm{C}_{4}$ plants. Generally, $\Delta^{13} \mathrm{C}$ increases with irradiance in $\mathrm{C}_{4}$ plants. Water use efficiency also influences $\mathrm{C}_{4}$ plants $\Delta^{13} \mathrm{C}$; however, with an opposite trend compared with $\mathrm{C}_{3}$ plants. Also, there may be a trend for increased isotope carbon discrimination with increased drought stress in $\mathrm{C}_{4}$ plants (Murphy and Bowman, 2009).

Global atmospheric circulation of water is the most important process that influences global distribution of $\delta^{18} \mathrm{O}$ and $\delta^{2} \mathrm{H}$. Oxygen and hydrogen isotope ratios of water change primarily from the isotopic discrimination by sea water evaporation and precipitation. The standard mean ocean water (SMOW) is the international standard for $\delta^{18} \mathrm{O}$ and $\delta^{2} \mathrm{H}$, which is $0 \%$, by convention. Furthermore, $\delta^{18} \mathrm{O}$ and $\delta^{2} \mathrm{H}$ ratios become negative due to differential evaporation between heavier and lighter molecules, where lighter molecules evaporate more easily. In the process of rain formation and precipitation, clouds turn more negative as they advance toward the continent. In this way, $\delta^{18} \mathrm{O}$ and $\delta^{2} \mathrm{H}$ ratios present latitudinal, longitudinal and/or altitude variation, undergoing continental effects.

At smaller scales, water isotopes differ according to the scale and processes that drive the hydrological cycle. In a watershed, regardless of its extent, the water isotopic variation goes beyond the influence of precipitation. The $\mathrm{O}$ and $\mathrm{H}$ isotope ratios of surface water depend mainly on the water source (Bowen and Good, 2015; Liu et al. 2010; Birkel et al., 2018) and downstream transport-related processes during the terrestrial water fluxes in a watershed (Jasechko et al., 2013). Differences in soil texture or hillslope angle can drive differential variation in the evaporation leading to variation in water isotope values at local scales (Mueller et al., 2014). Differences in environmental conditions (temperature and air humidity) influence leaf water evaporation leading to possible variation of tissue $\mathrm{O}$ and $\mathrm{H}$ isotope ratios and it can vary according to the plant species (West et al., 2008).

The spatial variation of $\delta^{15} \mathrm{~N}$ depends on a complex set of processes. Each process of oxidation and reduction of nitrogen causes isotope fractionation. Nitrogen makes up about $78 \%$ of the atmosphere in the form of $\mathrm{N}_{2}$, a little-reactive gas. This gas is the international standard for $\delta^{15} \mathrm{~N}$ which is $0 \%$, by convention. Processes such as dry and/or wet deposition of $\mathrm{N}$, and 
decomposition of organic matter transform $\mathrm{N}$ into more reactive forms. When nitrogen is transformed from $\mathrm{N}_{2}$ to $\mathrm{NH}_{3}$ and $\mathrm{NH}_{4}{ }^{+}$, assimilated by the organisms and transformed into organic molecules, $\delta^{15} \mathrm{~N}$ values of the substrate increase. Therefore, soil $\delta^{15} \mathrm{~N}$ is generally high, especially in tropical ecosystems (Martinelli et al., 1999).

Climatic influences on soil $\delta^{15} \mathrm{~N}$ values occur mainly due to the higher gaseous $\mathrm{N}$ losses in hot/dry places than in wet/cold places (Craine et al., 2015a). High values of $\delta^{15} \mathrm{~N}$ in the soil can indicate high relative losses of $\mathrm{N}$ for the atmosphere while $\mathrm{N}$ losses due to leaching and erosion do not cause significant fractionation. Soil $\delta^{15} \mathrm{~N}$ varies as a function of clay content and soil organic carbon concentration at global scale (Craine et al., 2015a) while at local and regional scales, soil $\delta^{15} \mathrm{~N}$ values are a function of organic matter decomposition (Craine et al., 2015b). Generally, the higher the level of organic matter decomposition, the greater the soil $\delta^{15} \mathrm{~N}$ (Craine et al., 2015b). Moreover, topographic position influences soil particle size by erosion and deposition processes and can be an important predictive variable of the nitrogen cycle, which consequently influences soil $\delta^{15} \mathrm{~N}$ spatial variation (Berhe et al., 2018).

\subsection{Scaling isoscapes}

Scale is a fundamental aspect of studying all phenomena and processes that vary in space and/or time (Goodchild, 2011). In general, a scale reflects the limit of a given phenomenon representation. Several studies use categoric terminology from geographical scale approach in the application or elaboration of isoscapes or in works on processes that lead to a spatial variation of isotopic fractionation and discrimination, which can be used as predictive variables for isoscape elaboration (eg.: landscape-scale - Bai et al., 2009; continental-scale - Powell et al., 2012; ecosystem-scale Wang et al., 2013; community-scale - Rascher et al., 2012).

Large-scale isoscapes often need to be simplified and generalized due to the necessary match with secondary data sources available at these scales (Bowen, 2010a). In this sense, global or continental-scale isoscapes may not be suitable for landscape-scale applications without going through a downscaling process considering more variables. Likewise, isoscapes elaborated on very detailed scales may not address issues at larger scales (Bowen, 2010a).

The isotope ratio of a given substrate varies with time, location, and spatially. Therefore, depending on the chosen scale, the predictive variables of a given isotopic ratio may change. The spatial variation of water stable isotopes of precipitation $\left(\delta^{18} \mathrm{O}\right.$ and $\left.\delta^{2} \mathrm{H}\right)$, for example, is clearly influenced mainly by climatic patterns, with the main variables predicting the annual mean precipitation and temperature (Terzer et al., 2013). However, in smaller scales, the influence of other variables such as topography may be more evident (Baisden et al., 2016).

\subsection{Mapping isoscapes}

One of the main principles of isoscapes is to determine isotopic composition in places where there is no sampling, extrapolating a limited number of sampled sites. Therefore, we mainly use methods and algorithms from the geostatistics. The choice of the appropriate method for the mapping depends on the purpose of the work, the number of spatially explicit dependent variables and predictors available, and the scale. At the local and regional scale, it is feasible to collect in the field to feed isoscapes models. Usually, these studies have used ordinary kriging after semivariogram fit to construct the isoscapes (Oliver and Webster, 2014).

Isoscapes with larger scales are usually built by the compilation of data from literature. Another way is setting up global networks of isotopic monitoring. As an example, $\delta^{18} \mathrm{O}$ and $\delta^{2} \mathrm{H}$ isoscapes in water were used to compile the GNIP database that has been applied in hydrological and ecological approaches in many spatial scales (IAEA/WMO, 2015).

Spatial autocorrelation is considered as a fundamental condition for the application of geostatistical methods. That is, values from nearby places tend to be more similar than values from places more distant in space. In this sense, the independent or predictive variable must influence the values of the target variable, which are the stable isotope values. Geostatistical 
models usually bring an error that must be measured and considered in the studies. The model settings seek to reduce the error, increasing accuracy.

When the spatial process influencing the variable is well-known, the search for a methodological standardization is more feasible. That is the case of the influence of atmospheric water circulation on precipitation $\delta^{18} \mathrm{O}$ and $\delta^{2} \mathrm{H}$, for example, which allows the application of special regression in most mappings (Bowen, 2010b).

Most of the well-known global isoscapes are for $\delta^{18} \mathrm{O}$ and $\delta^{2} \mathrm{H}$, and they are basically based on equations of spatial regressions, with variations and adaptations between studies. Since there are global isoscapes of environmental elements such as precipitation of water, they can be adjusted for global isoscapes of biological tissues, as was done for leaf water (West et al., 2010) and bird feathers (Bowen et al., 2005; Hobson et al., 2012a). It is important to highlight here the work of Terzer et al. (2013) that proposed a new approach to raise accuracy of $\delta^{18} \mathrm{O}_{\mathrm{p}}$ and $\delta^{2} \mathrm{H}_{\mathrm{p}}$ isoscape global models, called Regionalized Cluster-based Water Isotope Precipitation (RCWIP). The method differs from previous ones because the authors made a more accurate model from a set of regionalized multivariate regression equations. The predictive variables were gridded climatic and geographic variables (elevation, latitude / longitude). Terzer et al. (2013) compared the results with the model of Bowen and Wilkinson (2002), showing that uncertainty generally decreased. These results are available for download on the internet in raster format with 10' x 10' spatial resolution on http://www.iaea.org/water.

The only existing global nitrogen isoscape was proposed by Amundson et al. (2003), based on a regression using global patterns of precipitation and temperature as predictive variables. They used values of foliar $\delta^{15} \mathrm{~N}$, soil $\delta^{15} \mathrm{~N}$, and enrichment factor available in the literature at that time, showing that, on a global scale, soil and plant $\delta^{15} \mathrm{~N}$ have a negative relation with MAP and positive correlation with MAT. It served as a first proxy of $\delta^{15} \mathrm{~N}$ global distribution. However, it presented considerable limitations due to the complexity of factors that affect $\delta^{15} \mathrm{~N}$ fractionation, many gaps in spatial distribution data, which results in augmented error in the final model (Pardo and Nadelhoffer, 2010).

For carbon isoscapes, Still and Powell (2010) developed a methodology to estimate the percentage of $\mathrm{C}_{3}$ and $\mathrm{C}_{4}$ plants by area unit, allowing $\delta^{13} \mathrm{C}$ plant spatial distribution pattern estimation in a large mapping scale. Powell et al. (2012) used similar methodology to map $\delta^{13} \mathrm{C}$ in South America in 2000, using empirical measurements of plants and soils. They estimated $\delta^{13} \mathrm{C}$ values for plants and soil organic matter from vegetation type mapping (grasses, shrubs and trees) by classifying each pixel of an image as potentially favorable for $\mathrm{C}_{3}$ plant or $\mathrm{C}_{4}$ plant. The authors used temperature and precipitation dataset incorporated to previous classifications of agricultural cover and type of crop. First, they considered vegetation pattern and visual interpretation of satellite image and incorporated information of managed agro-ecosystems. Second, they partitioned the area considered herbaceous in the previous step in natural grasses percentage and crop percentage based on global data of agricultural area distribution, separating in $\mathrm{C}_{3}$ and $\mathrm{C}_{4}$ plant culture from a global database of types of agriculture. This approach may be applied at a regional scale by incorporating new datasets that represent regional relationships between ${ }^{13} \mathrm{C}$ discrimination and abiotic factors.

\section{MAIN APPLICATIONS OF THE ISOSCAPES}

\subsection{Water isoscapes}

Global and regional $\delta^{18} \mathrm{O}$ and $\delta^{2} \mathrm{H}$ isoscapes provide information that integrate a number of water cycle mechanisms and have strong spatial correlation (Bowen and Good, 2015). This approach serves as base to models that assign samples to their regions of origin, such as animal migration and forensic models. Due to the importance and utility of maps for water $\delta^{18} \mathrm{O}$ and $\delta^{2} \mathrm{H}$, many works adapted methodologies by downscaling precipitation, surface water and 
groundwater isoscapes for different locations. Water isoscapes have been used to measure contributions of surface water and groundwater to rivers, water loss to atmosphere through evaporation or transpiration, and rain-type contribution to total precipitation (Aggarwal et al., 2016). Precipitation $\delta^{18} \mathrm{O}$ isoscapes also contribute to the understanding of climatic variations and anomalies (Kern et al., 2014) and the determination of seasonal variation in water sources (Brooks et al., 2012). In the latter, during the dry season, the major contribution was found to be from snow accumulated at higher altitudes (60-80\%), helping to understand the vulnerability of the Willamette River hydrographical system in the climate change scenario (Brooks et al., 2012).

\subsection{Isoscapes on ecosystem ecology approach}

Isoscapes have been used in the ecosystem approach mainly to provide a basis for studies of carbon and nitrogen biogeochemical cycles from local to global scales.

At the global scale, atmospheric and plant $\delta^{13} \mathrm{C}$ isoscapes provide fundamental information to the comprehension of $\mathrm{CO}_{2}$ exchanges between the biosphere and atmosphere by calculating net assimilation of carbon by plants based on carbon discrimination models (Lloyd and Farquhar, 1994; Suits et al., 2005); global plant $\delta^{13} \mathrm{C}$ isoscape models have great potential to improve estimates of the carbon sinks and sources spatial distribution, knowledge about plant physiology, and their interaction with climatic and edaphic factors (Powell et al., 2012); global isoscapes of soil $\delta^{15} \mathrm{~N}$ integrate important information about $\mathrm{N}$ global input and output tendencies of ecosystems (Amundson et al., 2003; Houlton et al., 2015).

At smaller scales, isoscapes have been used for both aquatic and terrestrial environments with an ecosystem approach to understand regional and local patterns of carbon and nitrogen cycles as well as human activities and local environmental changes are affecting the dynamics of these elements. In aquatic ecosystems, $\delta^{13} \mathrm{C}$ and $\delta^{15} \mathrm{~N}$ isoscapes have been coupled with various elemental ratios to analyze nutrient dynamics ( $\mathrm{N}$ and $\mathrm{P}$ ) (Fourqurean et al., 2015). In terrestrial ecosystems, soil $\delta^{15} \mathrm{~N}$ spatial variation may be shaped considering elevation, which has a direct relationship to climatic patterns (e.g.: MAT and MAP) (Arnold et al., 2009; Weintraub et al., 2016), but may also help to compose future predictive models about nutrient cycling and $\mathrm{CO}_{2}$ emission in a climate change scenario (Houlton et al., 2015). $\delta^{13} \mathrm{C}$ and $\delta^{15} \mathrm{~N}$ isoscapes have also been applied to measure spatial correlation of soil $\delta^{13} \mathrm{C}$ in natural environments and pastures (Powers, 2006), to evaluate invasive plant effects in local ecosystem processes (Bai et al., 2009; 2012a; 2013; Rascher et al., 2012; Hellmann et al., 2016a; 2016b; 2017; Nielsen et al., 2016) and to assess the effects of land use change to nutrient cycle in rural areas (Nitzsche et al., 2016) as well as in urban areas (Boeckx et al., 2006). Local $\delta^{13} \mathrm{C}$ and $\delta^{15} \mathrm{~N}$ isoscapes have been also used to track soil organic matter dynamics. For instance, variations in tropical forest soil $\delta^{15} \mathrm{~N}$ may also be explained by topographic variations, mainly by slope (Hilton et al., 2013; Weintraub et al., 2015) and elevation (Arnold et al., 2009; Weintraub et al., 2016).

\subsection{Isoscapes on animal movement and biological conservation studies}

There are two major approaches to use isoscapes in animal migration studies: nominal assignment and continuous surface assignment (Wunder, 2012). Nominal assignment approach divides the continuous surface with isotopic ratios (predictive variables) in smaller named blocks, easier to manipulate (categoric variables). The most-used methods in the nominal assignment approach are decision trees or discriminatory functions that create attributions and clusters (Hobson et al., 2012b; Vander Zanden et al., 2015). Continuous surface assignment approach is based on continuous surface models with isotopic ratios attributed to each pixel on a model. In these cases, the continuous surface approach requires a small set of sample data adjusted to inorganic variable models (such as precipitation, for instance) (Wunder, 2012). 
Assignments have usually been made by applying Bayesian analysis in order to estimate the likelihood that each isoscape pixel represents the origin of a given sample. The same approach is used in forensic studies (see section below). Some prior information may lead to greater likelihood that an unknown sample may have originated from an area. In the absence of isotope data, given the greater natural abundance of individuals from a same species in a region versus in another region, it is reasonable to think that the target individual would have a greater chance to have come from the former region. This way of thinking may be traduced to mathematical terms using Bayesian rules: $P(B \mid A)=P(A \mid B) * P(B) / P(A)$, where, $P(B \mid A)$ is the posterior probability of an event $B$ given event $A, P(A \mid B)$ is the probability of the observed data given the model parameters (for example, the normal probability function cited below), $P(B)$ is the prior probability for $B$ and $P(A)$ is a marginal probability that serves as a normalizing constant.

There are several algorithms and computational platforms that support the Bayesian analysis specific for sample assignment to isoscapes. One of the most-used platforms is the IsoMAP, cyber-GIS system that supports basic isoscape modeling and sample assignment based on Bayesian analysis (http://isomap.org; Bowen et al., 2014). Recently, many packages have emerged on the R statistical computing environment (R Core Team, 2018) that permit geostatistical analyses, isoscape modelling, and sample assignment. Some of them combined different GIS packages in one specific for isoscape assignment, such as IsoriX package, for example (Courtiol et al., 2019).

Assignment models use tissue isoscape as a probability surface, where an unknown origin sample value may be assigned to a region as a function of a normal distribution, given its isotopic value and the expected standard deviation (Wunder, 2012; Reed et al., 2018; Hobson et al., 2018). For that reason, the construction of tissue isoscapes is a priority for studies on animal migration. Studies with this objective should consider the characteristics of each species and generate isoscape models with appropriate spatial resolution. Also, the majority of existing models are static, not taking into account temporal variation that may be incorporated to animal tissue. Isoscapes based on global databases, for example, should be associated with fieldvalidated samplings and other, more refined, local climatic models (Hobson et al., 2010). The mechanisms of tissue renewal and how they affect isotopic fractionation in the animal must be considered in the analysis (Wunder and Norris 2008). Studies about migratory species using isoscapes in countries with few available data should elaborate ground-validated models for the species in question (Gutiérrez-Expósito et al., 2015). The tissue-calibrated isoscape can be made by using the residual from a regression analysis between the environment isoscape and the target tissue isotopic value (Hobson et al., 2018). The tissues to calibrate the isoscapes must have known origins.

Scientists must be aware of the challenges of using organic tissue for stable isotope analysis, mainly for $\delta^{2} \mathrm{H}$ values (Hobson et al., 2012a; Soto et al., 2017). Samples for this type of analysis are very sensitive to contamination by any water from the natural ambient humidity. The analysis of the same sample at different sites may also affect the final result, which can be solved by more intensive drying of the sample (Soto et al., 2017). Even more complex is the exchangeable nature of some hydrogen molecules, which may affect the final bulk tissue $\delta^{2} \mathrm{H}$ value. That is due to the characteristics of some chemical structures of the materials, such as amino $\left(\mathrm{NH}_{2}\right)$, carboxyl $(\mathrm{COOH})$, hydroxyl $(\mathrm{OH})$, or thiol $(\mathrm{SH})$, which can exchange hydrogen atoms with ambient water (Meier-Augenstein et al., 2013). Therefore, exchangeable hydrogen must be considered in the analysis to maintain the accuracy of assignment models with precipitation isoscapes (Meier-Augenstein et al., 2013; Soto et al., 2017).

Building an organic tissue $\delta^{2} \mathrm{H}$ dataset must follow controlled methods to determine nonexchangeable ${ }^{2} \mathrm{H}$ abundance in animal tissue, so the analysis can be validated and applied in spatial models (Meier-Augenstein et al., 2013). Some methods have recently been accessed in 
an attempt to standardize $\delta^{2} \mathrm{H}$ analyzes on tissues in different laboratories and should be considered in future analyses (Soto et al., 2017). These challenges must be considered on any analysis that uses organic tissue $\delta^{2} \mathrm{H}$ to track animal movement, as well as any forensic application involving tracking humans, food provenance, and illegal trade of wildlife, timber and drugs.

Most papers on the use of isoscapes in animal migration studies are focused on birds, due to the large number of migratory species (eg Vander Zanden et al., 2015; Reed et al., 2018). However, the isoscape approach has been used in studies of the movement of any species or group of animals that exhibit some geographic variation during the life cycle. In terms of wild fauna conservation studies, regional isoscapes have been used with great potential to assist decision makers (Hénaux et al., 2011). For example, Hénaux et al. (2011) observed the dispersion routes of pumas (Puma concolor) using $\delta^{2} \mathrm{H}$ and $\delta^{13} \mathrm{C}$ isoscapes to approach prey with sedentary behavior, an important work in identifying critical conservation areas for big carnivores, and Rodríguez-Pérez et al. (2018) identified critical habitats of vaquitas (Phocoena sinus) using sediment and zooplankton $\delta^{13} \mathrm{C}$ and $\delta^{15} \mathrm{~N}$ isoscapes in marine ecosystems.

\subsection{Isoscapes on forensic applications}

The success of prior uses of animal-tissue isoscapes has led the increased use of isoscape approach in human forensic studies. Stable isotopes serve as geographical indications of illegal material seized, such as drugs or trafficked wild animals and have the potential to link these materials to geographic positions (Bowen et al., 2007; Ehleringer et al., 2008; Warner et al., 2018; Chesson et al., 2018).

The success of using isoscapes to help solve forensic questions depends on a series of factors. First, is important to know how mechanisms and chemical materials used on fixation and storage affect the material, component or organism isotope ratio. Second, is necessary to know the predictive power of the model, which may be recognized from a regression, to describe relations between a specimen isotopic ratio with environmental variables (Ehleringer et al., 2010).

Ehleringer et al. (2008) mapped $\delta^{2} \mathrm{H}$ and $\delta^{18} \mathrm{O}$ human hair for the United States, while Valenzuela et al. (2011) elaborated human hair isoscapes for the United States, using $\delta^{15} \mathrm{~N}$, $\delta^{13} \mathrm{C}$, and $\delta^{34} \mathrm{~S}$. Both papers discussed the possible applications of this model to identify the region of unidentified human origin, movement reconstruction, and studies on human diet. Isoscape from tap water is also a solid base to forensic studies (Bowen et al., 2007) and has been useful in identifying human geographical origin (Warner et al., 2018). Hydrogen and oxygen isoscapes have been also employed for the identification of the geographic region of food production, such as wine, olive oil, coffee, meat (Ehleringer et al., 2000; Carter et al., 2015; Chiocchiani et al., 2016), beer, bottled water, soda, and milk (Chesson et al., 2010a; 2010b).

Although the use of isoscapes are efficient in numerous forensic studies, generally the models are not capable of predicting the exact specimen origin place due to climatic conditions that shape stable isotopes spatial patterns in similar ways in different regions (Ehleringer et al., 2010). If there is some previous knowledge of the specimens' probable origin areas or assistance from other complementary tools, it is possible to increase the predictive capacity of coupled models. As an example, Mallette et al. (2016) used $\mathrm{O}$ and $\mathrm{H}$ isoscapes coupled to alkaloid studies to detect the possible origin of seized cocaine in the United States among 19 crop areas in South America; but also, they could compare cocaine isotopic ratios to a geographically validated database and that allowed the authors to discover new cocaine cultivation areas formerly unknown. 


\section{POTENTIAL USE OF ISOSCAPES IN BRAZIL}

In Brazil, the number of studies using light stable isotope ratios to track local and regional carbon and nitrogen dynamics in the soil-plant-atmosphere system from different Brazilian regions has grown considerably in the last decades: in the North region - Amazonia (Ometto et al., 2002; 2005; 2006; Pérez et al., 2006; Nardoto et al., 2008; 2014); northeastern region Caatinga (Teixeira et al., 2006; Freitas et al., 2010), Central region - Cerrado (Bustamante et al., 2004; Coletta et al., 2009; Viani et al., 2011), southeastern region - Atlantic forest (Lins et al., 2016; Vitoria et al., 2018).

The combination of $\delta^{15} \mathrm{~N}$ and $\delta^{13} \mathrm{C}$ has been the basis for studies about diet of different animals such as aquatic macrofaunal (Hardt et al., 2013; Castro et al., 2016), fishes and dolphins (Di Beneditto et al., 2013), arthropods (Salgado et al., 2014) and small mammals (Galetti et al., 2016), and human diet in different regions of Brazil (Nardoto et al., 2006, 2011; Gragnani et al., 2014; Rodrigues et al., 2016).

The $\delta^{2} \mathrm{H}$ and $\delta^{18} \mathrm{O}$ have been applied to hydrological cycle studies in Brazil. These isotopes have been applied in the understanding of local and regional hydrological cycles (Martinelli et al., 2004; Soler i Gil and Bonotto, 2014). Mixture models of $\delta^{2} \mathrm{H}$ and $\delta^{18} \mathrm{O}$ indicated the role of plant transpiration and soil evaporation on local hydrological cycle in Amazonia (Moreira et al., 1997), Cerrado (Jackson et al., 1999), and Atlantic forest ecosystems (Cassana et al., 2015). An isotope map has been made to verify chemical and isotopic characteristics at the west portion of the Guarani Aquifer System (among the states of Mato Grosso do Sul, Mato Grosso and Goiás) for a paleoclimate study (Gastmans et al., 2010) while Martinelli et al. (2004) showed the potential of using $\delta^{2} \mathrm{H}$ and $\delta^{18} \mathrm{O}$ isotopes from precipitation and river water in the Piracicaba's River Basin's hydrological monitoring station, in São Paulo State.

The applications of stable isotopes to detect food authentication and adulteration have also been used in Brazil to evaluate the quality and origin of Brazilian wines (Martinelli et al., 2003) and beers (Mardegan et al., 2013), soy sauce (Morais et al., 2018), but also to determine differences in diet of barn versus free-range chickens for studying animal nutrition with food authentication implications (Coletta et al., 2012).

Stable-isotope forensic studies have sporadically been used in Brazil. $\delta^{15} \mathrm{~N}$ and $\delta^{13} \mathrm{C}$ helped to identify the origin of Brazilian marijuana seized (Shibuya et al., 2007), to trace origin and effect of illegal discharge of residues in streams and sediment (Barbieri et al., 2014; Roth et al., 2016), but also for an isotopic assessment to help understand the effects of the 2012 Brazilian Forest Act on tropical riparian zones (Salemi et al., 2016).

Very few studies using $\delta^{13} \mathrm{C}$ spatial patterns have been employed to measure land-use effects in aquatic (Sanaiotti et al., 2002; Augusto et al., 2015) and terrestrial ecosystems (Assad et al., 2013; Salemi et al., 2016; Figueira et al., 2016), which, therefore, might closely fit what has been applied in Brazil in terms of the isoscape approach in any published study led by Brazilian research groups.

\subsection{Perspectives of using isoscapes in Brazil}

Published global and continental isoscape models can be downloaded for the Brazilian context. These isoscapes may serve as a first approximation to perform larger scales mapping in Brazilian biomes. $\delta^{13} \mathrm{C}$ isoscape elaborated by Powell et al. (2012) for South America shows carbon stable isotope spatial distribution patterns along Brazilian biomes (Figure $1 \mathrm{~A}$ ). The equations from Amundson et al. (2003) for soil and vegetation $\delta^{15} \mathrm{~N}$ may be applied to Brazil from records of spatial climatic variables (Figura $1 \mathrm{~B}$ ).

Global precipitation $\delta^{2} \mathrm{H}$ and $\delta^{18} \mathrm{O}$ isoscapes can also be downloaded and easily applied in Brazilian scale (Figure 2). However, elaboration of local and regional isoscapes in the Brazilian context is essential in order to reduce associated model errors. Developing precipitation 
isoscape models specific for Brazil is imperative, since current global models mask part of the natural variations of isotopic ratios. For instance, average rates presented in Figure 2, show a significantly lower spatial variation in comparison to temporal and spatial fluctuation found by Soler i Gil and Bonotto (2014) only in the area of São Paulo State.
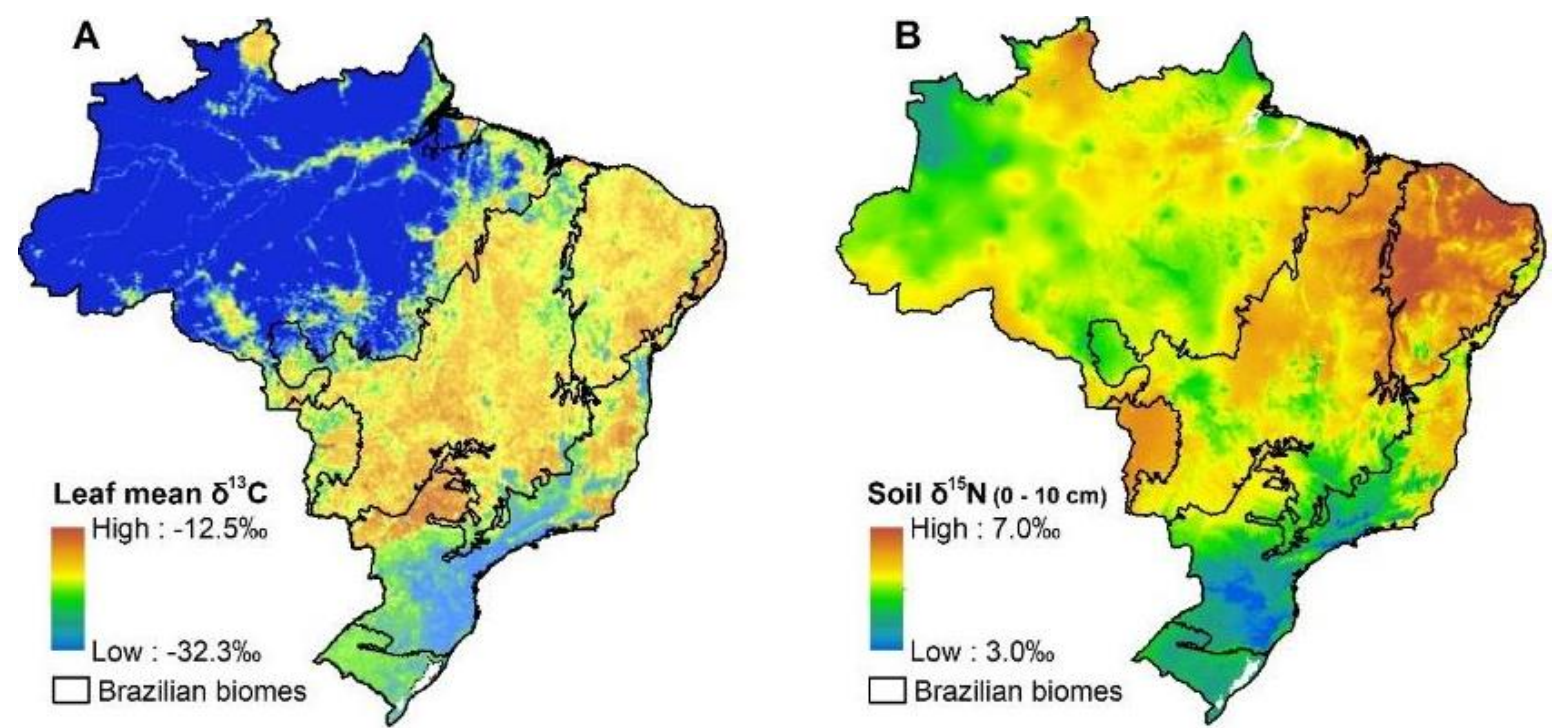

Figure 1. Plant $\delta^{13} \mathrm{C}$ isoscape from Powell et al. (2012) with author's consent (A); and soil $\delta^{15} \mathrm{~N}$ isoscape based in Amundson et al. (2003) equation for $0-10 \mathrm{~cm}$ depth $\left(\delta^{15} \mathrm{~N}_{\mathrm{soil}(0-10)}=0.134 *\right.$ MAT $-0.0005 * \mathrm{MAP}+3.1985)$ applied using climatic data from http://www.worldclim.org to elaborated (B).
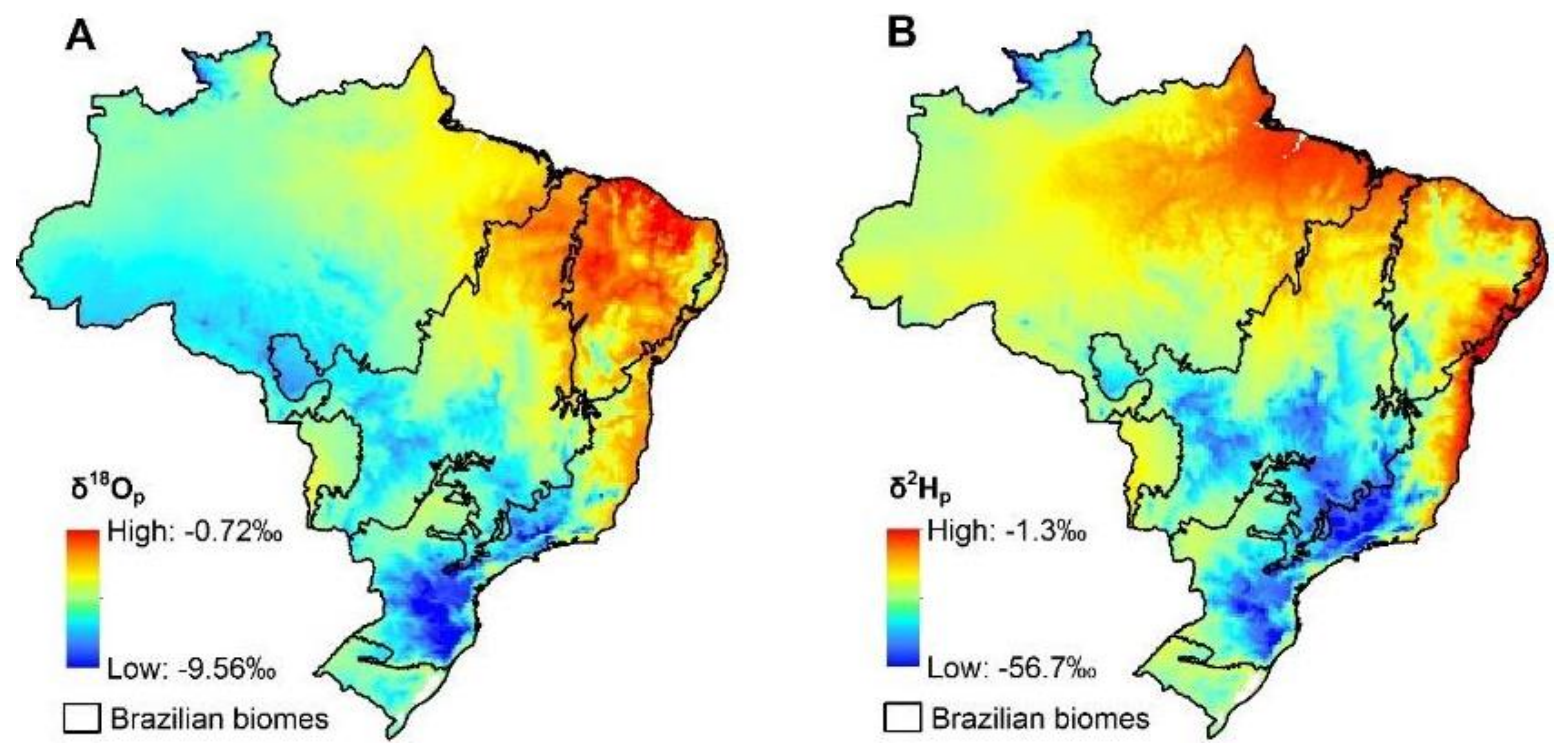

Figure 2. Mean annual precipitation $\delta^{18} \mathrm{O}(\mathrm{A})$ and $\delta^{2} \mathrm{H}(\mathrm{B})$ isoscapes. Data were downloaded from http://www.waterisotopes.org.

Taking into account the number of studies that have been using the stable isotope approach in Brazil together with the facility to use the equations and methods already tested and applied worldwide, the potential to develop carbon, nitrogen, oxygen and hydrogen and isoscapes with improved scale will definitely support both basic and applied studies in different areas of knowledge as pointed out in Section 4 above.

In terms of developing $\delta^{2} \mathrm{H}$ and $\delta^{18} \mathrm{O}$, local to regional isoscapes to study hydrological cycles in different regions of Brazil could be easily applied to groundwater management in Brazil and should be complemented by spatial modelling for isoscape creation that would 
facilitate data interpretation. There are 26 geographic locations with precipitation stable isotope historic data from GNIP stations in Brazil, which are available for download in shapefile format (http://wateriso.utah.edu/). Currently, 10 GNIP monitoring stations are operating in Brazil (Peeva, 2018). This amount of GNIP stations cannot represent the climatic and hydrographic diversity for the Brazilian territory. Some alternatives are suggested in the literature, such as the Ehleringer et al. (2008) work collecting tap water and human hair, or using specific resident species (Hobson et al., 2009) to construct indirectly water based isoscapes in a continental level. These approaches can be used to fill-in gaps on water based isoscapes for the continental territory of Brazil.

Future $\delta^{13} \mathrm{C}$ isoscapes for Brazil should be made using samples with large spatial representation, such as the one performed by Assad et al. (2013) to study changes in carbon stock caused by land-use changes. It may help to decrease model errors. For the Cerrado region, for example, Powell et al. (2012) indicated considerable uncertainty due to huge land cover heterogeneity in Cerrado biome. Brazilian researchers can integrate soil and vegetation samples from collections of previous field work and publications to increase the number of sampling sites for biogeochemical studies, both for carbon and nitrogen stable isotopes.

Local and regional biogeochemical changes result in problems related to $\mathrm{N}_{\mathrm{r}}$ in Latin America (Austin et al., 2013), especially in Brazil. $\delta^{15} \mathrm{~N}$ isoscapes for vegetation and, mainly, for soil are important tools to study $\mathrm{N}$ input and output mechanisms from ecosystems (Bai et al., 2012b, Houlton et al., 2015). Nitzsche et al. (2016) discussed the importance of $\delta^{15} \mathrm{~N}$ mapping in complex agricultural areas to disclose results to farmers and decision makers. It may be applied in Brazil, considering the large extension of agricultural areas. Another possibility would be to map $\delta^{15} \mathrm{~N}$ in agricultural areas considering landforms, potential ways in which the land can influence soil characteristics and agricultural productivity (Siqueira et al., 2010). In this case, a regional and local soil $\delta^{15} \mathrm{~N}$ isoscape could point to the topographic position where $\mathrm{N}$ losses to the atmosphere or leaching area are happening, aiding agricultural management.

Some plants used in agriculture and livestock were introduced in natural ecosystems in Brazil. There are at least 54 potentially invasive plants in Brazil and their effects on local biogeochemical cycles are little known (Zenni and Ziller 2011; Dias et al., 2013). Similar approaches as above described (Bai et al., 2013) should be used to help in the understanding of invasion vectors and the biogeochemical cycle changing (Rascher et al., 2012, Bai et al., 2012a, Hellmann et al., 2016a, 2017).

Considering the extensive biodiversity and animal migration in Brazil, existing global isoscape models may be used for first approximations of animal wintering and reproduction localities. Geographic assignment models of migratory birds to geographic origins have already been made for South America (García-Pérez and Hobson, 2014; Hobson and Kardynal, 2016). Despite the use of water isoscapes applicability to infer origin or wintering places of animals at regional and continental scales, the highest potential of this approach lies at medium to high latitude regions due to the strong spatial gradient of isotopic ratios in precipitation. However, this limitation does not narrow the application of isoscapes in issues of this nature in regions of low latitude, such as South America and Africa. In these cases, a multi-isotope approach coupling $\delta^{2} \mathrm{H}$ isoscapes with $\delta^{13} \mathrm{C}$ and $\delta^{15} \mathrm{~N}$ isoscapes may raise the inference efficiency (GarcíaPérez and Hobson, 2014; Hobson and Kardynal, 2016). Another way to raise the isoscape efficiency is to perform an integrated use with other tracing methods, such as satellite tracking or combined with genetic markers (Rundel et al., 2013).

Isoscape approach used in animal migration studies could be adapted to determine the origin of seized animals and trafficking routes. There is still a huge number of live animals and animal products being seized every year in illegal activities (Alves et al., 2012; Regueira and Bernard, 2012). Illegal animal trade usually results in the withdrawal of aminals from those 
natural origins and transporting them to other regions where illegal markets, intermediate sellers or final consumers are present (Alves et al., 2012; Destro et al., 2012). Transportation caused by illegal wildlife traffic may be compared to natural bird migration, as both imply animal displacement at a continental scale (Destro et al., 2012).

In the forensic context, many applications should be accomplished in numerous investigation cases, since it is usually necessary to link crime traces to their geographical origin (Cerling et al., 2016). In addition to wildlife illegal trade, other common crimes, such as illicit drug trafficking, wood trafficking, food frauds cases, and individual human crime investigations would benefit from isoscape approaches in the Brazilian context. All materials or components seized that go through isotopic analysis should have their isotopic ratios compared to spatial databases which may indicate the origin or traveled path (see Cerling et al., 2016). For example, the US Drug Enforcement Agency (DEA) has a drug signature program, with the aim to construct specific drugs isoscapes (Chesson et al., 2018). This initiative should be replicated here, for marijuana and cocaine drugs. Shibuya et al. (2007) studied different marijuana-producing regions in Brazil and could assign seized samples. This knowledge can be updated and used for drug enforcement.

Illegal logging in Brazil, specially in the Amazon region, is still a big issue, with selected species being collected using fraud in mechanisms of control (Brancalion et al., 2018). Considering the Brazilian potential for wood commercialization, certification of commercialized wood would benefit from the isoscape approach, considering the well-known relation between local water and wood isotopic ratios (Gori et al., 2018).

Provenance of food production for human consumption is also a forensic issue. Regional certified products have specific organoleptic and culinary qualities, such as wine, cheese, and coffee, which sometimes are subject to mislabeling or other fraud (Camim et al., 2017). Camim et al. (2017) reviewed methods and necessary legal aspects to state geographic origins of food products. Besides basic element isoscape knowledge, they state the importance of complementing isotopic information with standard values of authentic products in available databases.

\section{SYNTHESIS AND FUTURE}

The isoscape approach has been applied in different scales and its use as a basis for many scientific subjects has increased in the last decade. Its main advantage is deriving isotopic ratios with a statistical consistency in real sample points gap. Since spatial and temporal isotopic continuous maps integrate chemical processes occurring in ecosystems, the use of grid-based isoscape models has facilitated and simplified the isotope interpretation in different contexts, from terrestrial to aquatic ecosystems, either in natural or anthropic conditions.

Both global and regional $\delta^{2} \mathrm{H}$ and $\delta^{18} \mathrm{O}$ isoscapes indicate elements of water cycle, such as inputs and outputs in water pools, and have helped in water management. However, these isoscapes are also used as tracers to identify origin of animals, products and chemical elements and may amplify their utility when coupled with $\delta^{15} \mathrm{~N}$ and/or $\delta^{13} \mathrm{C}$ isoscapes.

Existent global and continental isoscapes can already be framed into the Brazilian boundaries and applied in many studies, although they are general models with relatively low spatial resolution, not being able to represent regional or local variations of stable isotope values. However, by improving technologies and possibilities of isoscape applications, studies tend to seek more-refined isoscapes, with better spatial and temporal resolution. There is a tendency pointed out by Bowen (2010a), a transition from descriptive models to comprehensive models, where isoscapes help explain ecosystem mechanisms and processes, and it must be incorporated into future studies in Brazil. The Brazilian challenge will be to develop regional and local isoscapes, upscaling existing isoscapes and/or elaborating new ones from new systematic sampling. 
There is a global trend for the development of an integrated and centralized isotopic database. An example is an initiative from scientists, museum curators, data analysts, and educators to build the IsoBank, which they say would be a dynamic and sustainable repository that would accelerate the resolution of urgent issues in all disciplines involving stable isotopes (Pauli et al., 2017).

Another example is the GNIP for precipitation data, which has currently 10 stations in operation in Brazil. The integration of laboratories and the establishment of a national network could increase the number of monitoring stations. However, to build a national network to collect water samples regularly and to have them analyzed to $\delta^{2} \mathrm{H}$ and $\delta^{18} \mathrm{O}$ is far from being an easy task considering the immense Brazilian territory and especially the logistics and infrastructure involved. It should take into account the need to measure the years on a regular basis (rainfall event or least monthly). Most important is to be aware of the global networks and to be integrated with them.

Brazil has a basic structure of laboratories that carry out isotopic analyses in the northeastern, central-western and southeastern regions; however, the challenge is to increase the amount of specific funding involving stable isotope research. The establishment of museum networks and integrated access to animal and plant collections has great potential to increase the spatial distribution of samples with isotopic values in Brazil. The same is true for an integrated network for accessing soil samples from collections in Brazilian laboratories. Both networks would improve the access to data and the construction of isoscapes to answer current issues in biogeochemistry, ecology, conservation and forensics.

\section{ACKNOWLEDGMENTS}

This study was financed in part by the Coordenação de Aperfeiçoamento de Pessoal de Nível Superior - Brasil (CAPES) - Finance Code 001. We would like to thank the Graduate Program of Environmental Sciences of University of Brasília for the financial support to English review. We would like to thank to the Graduate Program of Environmental Sciences of University of Brasília for the financial support to English review.

\section{REFERENCES}

AGGARWAL, P. K.; ROMATSCHKE, U.; ARAGUAS-ARAGUAS, L.; BELACHEW, D.; LONGSTAFFE, F. J.; BERG, P.; SCHUMACHER, C.; FUNK, A. Proportions of convective and stratiform precipitation revealed in water isotope ratios. Nature Geoscience, v. 9, p. 624-629. 2016. http://dx.doi.org/10.1038/ngeo2739

ALVES, R. R. N.; PEREIRA FILHO, G. A.; VIEIRA, K. S.; SOUTO, W. M. S.; MENDONÇA, L. E. T.; MONTENEGRO, P. F. G. P.; ALMEIDA, W. O.; VIEIRA, W. L. S. A zoological catalogue of hunted reptiles in the semiarid region of Brazil. Journal of Ethnobiology and Ethnomedicine, v. 8, n. 27, 2012. http://dx.doi.org/10.1186/17464269-8-27

AMUNDSON, R.; AUSTIN, A. T.; SCHUUR, E. A. G.; YOO, K.; MATZEK, V.; KENDALL, C.; UEBERSAX, A.; BRENNER, D.; BAISDEN, W. T. Global patterns of the isotopic composition of soil and plant nitrogen. Global Biogeochemical Cycles, v. 17, n. 1, p. 1031-1041. 2003. http://dx.doi.org/10.1029/2002GB001903

ARNOLD, J.; CORRE, M. D.; VELDKAMP, E. Soil N cycling in old-growth forests across an Andosol toposequence in Ecuador. Forest Ecology and Management, v. 257, n. 10, p. 2079-2087, 2009. 
ASSAD, E. D.; PINTO, H. S.; MARTINS, S. C.; GROPPO, J. D.; SALGADO, P. R.; EVANGELISTA, B.; VASCONCELlOS, E.; SANO, E. E.; PAVÃO, E.; LUNA, R.; CAMARGO, P. B.; MARTINELLI, L. A. Changes in soil carbon stocks in Brazil due to land use: Paired site comparisons and a regional pasture soil survey. Biogeosciences, v. 10, p. 6141-6160, 2013. http://dx.doi.org/10.5194/bg-10-6141-2013

AUGUSTO, F. G.; TASSONI FILHO, M.; FERRERA, A.; PEREIRA, A. L.; CAMARGO, P. B.; MARTINELLI, L. A. Land use change in the Atlantic Forest affects carbon and nitrogen sources of streams as revealed by the isotopic composition of terrestrial invertebrates. Biota Neotropica, v. 15, n. 2, 2015. http://dx.doi.org/10.1590/167606032015018814

AUSTIN, A. T.; BUSTAMANTE, M. M. C.; NARDOTO, G. B.; MITRE, S. K.; PÉREZ, T.; OMETTO, J. P. H. B.; ASCARRUNZ, N. L.; FORTI, M. C.; LONGO, K.; GAVITO, M. E.; MARTINELLI, L. A. Latin America's nitrogen challenge. Science, v. 340, p. 149, 2013. http://dx.doi.org/10.1126/science.1231679

BAI, E.; BOUTTON, T. W.; BEN WU, X.; LIU, F.; ARCHER, S. R. Landscape-Scale vegetation dynamics inferred from spatial patterns of soil $\delta^{13} \mathrm{C}$ in a subtropical savanna parkland. Journal of Geophysical Research: Biogeosciences, v. 114, n. 1, p. 1-10, 2009. http://dx.doi.org/10.1029/2008JG000839

BAI, E.; BOUTTON, T. W.; LIU, F.; BEN WU, X.; HALLMARK, C. T.; ARCHER, S. R. Spatial variation of soil $\delta^{13} \mathrm{C}$ and its relation to carbon input and soil texture in a subtropical lowland woodland. Soil Biology and Biochemistry, v. 44, n. 1, p. 102-112. 2012a. http://dx.doi.org/10.1016/j.soilbio.2011.09.013

BAI, E.; BOUTTON, T.; LIU, F.; WU, X.; ARCHER, S. ${ }^{15} \mathrm{~N}$ isoscapes in a subtropical savanna parkland: spatial-temporal perspectives. Ecosphere, v. 4, n. 1, p. 1-17, 2013. http://dx.doi.org/10.1890/ES12-00187.1

BAI, E.; HOULTON, B. Z.; WANG, Y. P. Isotopic identification of nitrogen hotspots across natural terrestrial ecosystems. Biogeosciences, v. 9, n. 8, p. 3287-3304, 2012b. http://dx.doi.org/10.5194/bg-9-3287-2012

BAISDEN, W. T.; KELLER, E. D.; VAN HALE, R.; FREW, R. D.; WASSENAAR, L. I. Precipitation isoscapes for New Zealand: enhanced temporal detail using precipitationweighted daily climatology. Isotopes in Environmental and Health Studies, v. 52, n. 4, p. 343-352, 2016. http://dx.doi.org/10.1080/10256016.2016.1153472

BARBIERI, C. B.; SARKIS, J. E. S.; MARTINELli, L. A.; BORDON, I. C. A. C.; MITTEREGGER, H.; HORTELLANI, M. A. Forensic evaluation of metals $(\mathrm{Cr}, \mathrm{Cu}, \mathrm{Pb}$, $\mathrm{Zn})$, isotopes $\left(\delta^{13} \mathrm{C}\right.$ and $\left.\delta^{15} \mathrm{~N}\right)$, and $\mathrm{C}: \mathrm{N}$ ratios in freshwater sediment. Environmental $\begin{array}{lllllll}\text { Forensics, } & \text { v. } & 15, & \text { n. } & 2, & \text { p. } & 134-146,\end{array}$ http://dx.doi.org/10.1080/15275922.2014.890144

BERHE, A. A.; BERNES, R. T.; SIX, J.; MARÍN-SPIOTTA, E. Role of soil erosion in biogeochemical cycling of essential elements: Carbon, Nitrogen, and Phosphorous. Annual Review of Earth and Planetary Sciences, v. 46, p. 521-548, 2018. https://doi.org/10.1146/annurev-earth-082517-010018 
BIRKEL, C.; HELLIWELL, R.; THORNTON, B.; GIBBS, S.; COOPER, P.; SOULSBY, C.; TETZLAFF, L.; SPEZIA, L.; ESQUIVEL-HERNÁNDEZ, G.; SÁNCHEZ-MURILLO, R.; MIDWOOD, A. J. Characterization of surface water isotope spatial patterns of Scotland. Journal of Geochemical Exploration, v. 194, p. 71-80, 2010. http://dx.doi.org/10.1016/j.gexplo.2018.07.011

BOECKX, P.; VAN MEIRVENNE, M.; RAULO, F.; VAN CLEEMPUT, O. Spatial patterns of $\delta^{13} \mathrm{C}$ and $\delta^{15} \mathrm{~N}$ in the urban topsoil of Gent, Belgium. Organic Geochemistry, v. 37, n. 10, p. 1383-1393. 2006. http://dx.doi.org/10.1016/j.orggeochem.2006.04.015

BOWEN, G. J. Isoscapes: Spatial pattern in isotopic biogeochemistry. Annual Review of Earth and Planetary Sciences, v. 38, n. 1, p. 161-187, 2010a. http://dx.doi.org/10.1146/annurev-earth-040809-152429

BOWEN, G. J. Statistical end geostatistical mapping of precipitation water isotope ratios. In: Isoscapes: Understanding movement, pattern, and process on earth through isotope mapping. Netherlands: Springer, p. 139-150, 2010b. http://dx.doi.org/10.1007/978-90481-3354-3_7

BOWEN, G. J.; EHLERINGER, J. R.; CHESSON, L. A.; STANGE, E.; CERLING, T. E. Stable isotope ratios of tap water in the contiguous United States. Water Resources Research, v. 43, p. 1-12, 2007. http://dx.doi.org/10.1029/2006WR005186

BOWEN, G. J.; GOOD, S. P. Incorporating water isoscapes in hydrological and water resource investigations. WIREs Water, v. 2, n. 2, p. 107-119. 2015. http://dx.doi.org/10.1002/wat2.1069

BOWEN, G. J.; LIU, Z.; VANDER ZANDEN, H. B.; ZHAO, L.; TAKAHASHI, G. Geographic assignment with stable isotopes in IsoMAP. Methods in Ecology and Evolution, v. 5, p. 201-206, 2014. https://doi.org/10.1111/2041-210X.12147

BOWEN, G. J.; REVENAUGH, J. Interpolating the isotopic composition of modern meteoric precipitation. Water Resources Research, v. 39, n. 10, p. 1-13, 2003. http://dx.doi.org/10.1029/2003WR002086

BOWEN, G. J.; WASSENAAR, L. I.; HOBSON, K. A. Global application of stable hydrogen and oxygen isotopes to wildlife forensics. Oecologia, v. 143, n. 3, p. 337-348, 2005. http://dx.doi.org/10.1007/s00442-004-1813-y

BOWEN, G. J.; WEST, J. B.; HOOGEWERFF, J. Isoscapes: Isotope mapping and its applications. Journal of Geochemical Exploration, v. 102, n. 3, p. v-vii. 2009. http://dx.doi.org/10.1016/j.gexplo.2009.05.001

BOWEN, G. J.; WILKINSON, B. Spatial distribution of $\delta^{18} \mathrm{O}$ in meteoric precipitation. Geology, v. 30, n. 4, p. 315-318, 2002. https://doi.org/10.1130/00917613(2002)030\%3C0315:SDOOIM\%3E2.0.CO;2

BRANCALION, P. H. S.; ALMEIDA, D. R. A.; VIDAL, E.; MOLIN, P. G.; SONTAG, V. E.; SOUZA, S. E. X. F.; SCHULZE, M. D. Fake legal logging in the Brazilian Amazon. Science Advances, v. 4, p. 1-7, 2018. http://dx.doi.org/10.1126/sciadv.aat1192

BROOKS, J. R.; WIGINGTON, P. J.; PHILliPS, D. L.; COMELEO, R.; COULOMBE, R. Willamette River Basin surface water isoscape $\left(\delta^{18} \mathrm{O}\right.$ and $\left.\delta^{2} \mathrm{H}\right)$ : temporal changes of source water within the river. Ecosphere, v. 3, n. 5, p. 1-21, 2012. http://dx.doi.org/10.1890/ES11-00338.1 
BUSTAMANTE, M. M. C.; MARTINELLI, L. A.; SILVA, D. A.; CAMARGO, P. B.; KLINK, C. A.; DOMINGUES, T. F.; SANTOS, R. V. ${ }^{15} \mathrm{~N}$ natural abundance in woody plants and soils of central Brazilian savannas (Cerrado). Ecological Applications, v. 14, n. 4, p. 200213, 2004. http://dx.doi.org/10.1890/01-6013

CAMIN, F.; BONER, M.; BONTEMPO, L.; FAUHL-HASSEK, C.; KELLY, S. D.; RIEDL, J.; ROSSMANN, A. Stable isotope techniques for verifying the declared geographical origin of food in legal cases. Trends in Food Science and Technology, v. 61, p. 176187, 2017. http://dx.doi.org/10.1016/j.tifs.2016.12.007

CARTER, J. F.; YATES, H. S. A.; TINGGI, U. The isotopic and elemental composition of roasted coffee as a guide to authenticity and origin. Journal of Agricultural and Food Chemistry, v. 63, p. 5771-5779, 2015. http://dx.doi.org/10.1021/acs.jafc.5b01526

CASSANA, F. F.; ELLER, C. B.; OLIVEIRA, R. S.; DILLENBURG, L. R. Effects of soil water availability on foliar water uptake of Araucaria angustifolia. Plant and Soil, v. 399, n. 1, p. 2015. http://dx.doi.org/10.1007/s11104-015-2685-0

CASTRO, D. M. P.; CARVALHO, D. R.; POMPEU, P. D. S.; MOREIRA, M. Z.; NARDOTO, G. B.; CALLISTO, M. Land use influences niche size and the assimilation of resources by benthic macroinvertebrates in tropical headwater streams. PLoS One, v. 11, n. 3, p. 119, 2016. http://dx.doi.org/10.1371/journal.pone.0150527

CERLING, T. E.; BARNETTE, J. E.; BOWEN, G. J.; CHESSON, L. A.; EHLERINGER, J. R.; REMIEN, C. H.; SHEA, P.; TIPPLE, B. J.; WEST, J. B. Forensic stable isotope biogeochemistry. Annual Review of Earth and Planetary Sciences, v. 44, p. 175-206, 2016. http://dx.doi.org/10.1146/annurev-earth-060115-012303

CERNUSAK, L. A.; UBIERNA, N.; WINTER, K.; HOLTUM, J. A. M.; MARSHALL, J. D.; FARQUHAR, GD Environmental and physiological determinants of carbon isotope discrimination in terrestrial plants. New Phytologist, v. 200, p. 950-965, 2013. http://dx.doi.org/10.1111/nph.12423

CHESSON, L. A.; BARNETTE, J. E.; BOWEN, G. J.; BROOKS, J. R.; CASALE, J. F.; CERLING, T. E.; COOK, C. S.; DOUTHITT, C. B.; HOWA, J. D.; HURLEY, J. M.; KREUZER, H. W.; LOTT, M. J.; MARTINELLI, L. A.; O'GRADY, S. P.; PODLESAK, D. W.; TIPPLE, B. J.; VALENZUELA, L. O.; WEST, J. B. Applying the principles of isotope analysis in plant and animal ecology to forensic science in the Americas. Oecologia, v. 187, p. 1007-1094, 2018. http://dx.doi.org/10.1007/s00442-018-4188-1

CHESSON, L. A.; VAlENZUELA, L. O.; O'GRADY, S. P.; CERLING, T. E.; EHLERINGER, J. R. Hydrogen and oxygen stable isotope ratios of milk in the United States. Journal of Agricultural and Food Chemistry, v. 58, n. 4, p. 2358-2363, 2010a. http://dx.doi.org/10.1021/jf904151c

CHESSON, L. A.; VALENZUELA, L. O.; O'GRADY, S. P.; CERLING, T. E.; EHLERINGER, J. R. Links between purchase location and stable isotope ratios of bottled water, soda, and beer in the united states. Journal of Agricultural and Food Chemistry, v. 58, n. 12, p. 7311-7316, 2010b. http://dx.doi.org/10.1021/jf1003539

CHIOCCHINI, F.; PORTARENA, S.; CIOLFI, M.; BRUGNOLI, E.; LAUTERI, M. Isoscapes of carbon and oxygen stable isotope compositions in tracing authenticity and geographical origin of Italian extra-virgin olive oils. Food Chemistry, v. 202, p. 291301, 2016. http://dx.doi.org/10.1016/j.foodchem.2016.01.146 
COLETTA, L. D.; NARDOTO, G. B.; LATANSIO-AIDAR, S. R.; ROCHA, H. R. Isotopic view of vegetation and carbon and nitrogen cycles in a Cerrado ecosystem, southeastern Brazil. Scientia Agricola, v. 66, n. 4, p. 467-475, 2009. http://dx.doi.org/10.1590/S010390162009000400006

COLETTA, L. D.; PEREIRA, A. L.; COELHO, A. A. D.; SAVINO, V. J. M.; MENTEN, J. F. M.; CORRER, E.; FRANÇA, L. C.; MARTINELLI, L. A. Barn vs. Free-range chickens: Differences in their diets determined by stable isotopes. Food Chemistry, v. 131, n. 1, p. 155-160, 2012. http://dx.doi.org/10.1016/j.foodchem.2011.08.051

COURTIOL, ALEXANDRE, FRANÇOIS ROUSSET, MARIE-SOPHIE ROHWÄDER, DAVID X. SOTO, LINN LEHNERT, CHRISTIAN C. VOIGT, KEITH A. HOBSON, LEONARD I. WASSENAAR, AND STEPHANIE KRAMER-SCHADT. Isoscape computation and inference of spatial origins with mixed models using the $\mathrm{R}$ package IsoriX. In: Tracking Animal Migration with Stable Isotopes, second. London: Elsevier, 2019.

CRAINE, J. M.; BROOKSHIRE, E. N. J.; CRAMER, M. D.; HASSELQUIST, N. J.; KOBA, K.; MARIN-SPIOTTA, E.; WANG, L. Ecological interpretations of nitrogen isotope ratios of terrestrial plants and soils. Plant and Soil, v. 396, n. 1, p. 1-26, 2015b. http://dx.doi.org/10.1007/s11104-015-2542-1

CRAINE, J. M.; ELMORE, A. J.; WANG, L.; AUGUSTO, L.; BAISDEN, W. T.; BROOKSHIRE, E. N. J.; CRAMER, M. D.; HASSELQUIST, N. J.; HOBBIE, E. A.; KAHMEN, A.; KOBA, K.; KRANABETTER, J. M.; MACK, M. C.; MARIN-SPIOTTA, E.; MAYOR, J. R.; MCLAUCHLAN, K. K.; MICHELSEN, A.; NARDOTO, G. B.; OLIVEIRA, R. S.; PERAKIS, S. S.; PERI, P. L.; QUESADA, C. A.; RICHTER, A.; SCHIPPER, L. A.; STEVENSON, B. A.; TURNER, B. L.; VIANI, R. A. G.; WANEK, W.; ZELLER, B. Convergence of soil nitrogen isotopes across global climate gradients. Scientific Reports, v. 5, 2015a. http://dx.doi.org/10.1038/srep08280

DESTRO, G. F. G.; PIMENTEL, T. L.; SABAINI, R. M.; BORGES, R. C.; BARRETO, R. Efforts to combat wild animals trafficking in Brazil. In: Biodiversity enrichment in a diverse world. Intech, p. 421-436, 2012. http://dx.doi.org/10.5772/48351

DI BENEDITTO, A. P. M.; REZENDE, C. E.; CAMARGO, P. B.; KEHRIG, H. A. Trophic niche comparison between two predators in northern Rio de Janeiro State, Brazil: a stable isotopes approach. Biota Neotropica, v. 13, n. 3, p. 29-33, 2013. http://dx.doi.org/10.1590/S1676-06032013000300002

DIAS, J.; FONTE, M. A. M. A.; BAPTISTA, R.; MANTOANI, M. C.; HOLDEFER, D. R.; TOREZAN, J. M. D. Invasive alien plants in Brazil: A nonrestrictive revision of academic works. Natureza \& Conservação, v. 11, n. $1, \quad$ p. $31-35,2013$. http://dx.doi.org/10.4322/natcon.2013.004

EHLERINGER, J. R.; BOWEN, G. J.; CHESSON, L. A.; WEST, A. G.; PODLESAK, D. W.; CERLING, T. E. Hydrogen and oxygen isotope ratios in human hair are related to geography. Proceedings of the National Academy of Sciences of the United States of America, v. 105, n. 8, p. 2788-2793, 2008. http://dx.doi.org/10.1073/pnas.0712228105

EHLERINGER, J. R.; CASALE, J. F.; LOTT, M. J.; FORD, V. L. Tracing the geographical origin of cocaine: Cocaine carries a chemical fingerprint from the region where the coca was grown. Nature, v. 408, p. 311-312, 2000. http://dx.doi.org/10.1038/35042680 
EHLERINGER, J. R.; THOMPSON, A. H.; PODLESAK, D.; BOWEN, G. J.; CHESSONLESLEY, L. A.; CERLING, T. E.; PARK, T.; DOSTIE, P.; SCHWARCZ, H. A framework for the incorporation of isotopes and isoscapes in geospatial forensic investigations. In: Isoscapes: Understanding movement, pattern, and process on earth through isotope mapping. Netherlands: Springer, p. 357-388, 2010. http://dx.doi.org/10.1007/978-90-481-3354-3_17

FARQUHAR, G. D.; LLOYD, J.; TAYLOR, J. A.; LAWRENCE, F. B.; SYVERTEN, J. P.; HUBICK, K. T.; WONG, C. S.; EHLERINGER, J. R. Vegetation effects on the isotope composition of oxygen in atmospheric $\mathrm{CO}_{2}$. Nature, v. 363, p. 439-443, 1993. http://dx.doi.org/10.1038/363439a0

FIGUEIRA, A. M. S.; DAVIDSON, E. A.; NAGY, R. C.; RISKIN, S. H.; MARTINELLI, L. A. Isotopically constrained soil carbon and nitrogen budgets in a soybean field chronosequence in the Brazilian Amazon region. Journal of Geophysical Research: Biogeosciences, v. 121, p. 2520-2529, 2016. http://dx.doi.org/10.1002/2016JG003470

FOURQUREAN. J. W.; MANUEL, S. A.; COATES, K. A.; KENWORTHY, W. J.; BOYER, J. N. Water quality, isoscapes and stoichioscapes of seagrasses indicate general $\mathrm{P}$ limitation and unique $\mathrm{N}$ cycling in shallow water benthos of Bermuda. Biogeosciences, v. 12 , n. 20, p. 6235-6249, 2015. http://dx.doi.org/10.5194/bg-12-6235-2015

FREITAS, A. D. S.; SAMPAIO, E. V. S. B.; MENEZES, R. S. C.; TIESSEN, H. ${ }^{15} \mathrm{~N}$ natural abundance of non-fixing woody species in the Brazilian dry forest (caatinga). Isotopes in Environmental and Health Studies, v. 46, n. 2, p. 210-218, 2010. http://dx.doi.org/10.1080/10256016.2010.488805

GALETTI, M.; RODARTE, R. R.; NEVES, C. L.; MOREIRA, M.; COSTA-PEREIRA, R. Trophic niche differentiation in rodents and marsupials revealed by stable isotopes. PLoS One, v. 11, n. 4, 2016. http://dx.doi.org/10.1371/journal.pone.0152494

GARCÍA-PÉREZ, B.; HOBSON, K. A. A multi-isotope $\left(\delta^{2} \mathrm{H}, \delta^{13} \mathrm{C}, \delta^{15} \mathrm{~N}\right)$ approach to establishing migratory connectivity of Barn Swallow (Hirundo rustica). Ecosphere, v. 5, n. 2, p. 1-12, 2014. http://dx.doi.org/10.3161/000164514X682896

GASTMANS, D.; CHANG, H. K.; HUTCHEON, I. Stable isotopes $\left({ }^{2} \mathrm{H},{ }^{18} \mathrm{O}\right.$ and $\left.{ }^{13} \mathrm{C}\right)$ in groundwaters from the northwestern portion of the Guarani Aquifer System (Brazil). Hydrogeology Journal, v. 18, n. 6, p. 1497-1513, 2010. http://dx.doi.org/10.1007/s10040-010-0612-2

GOODCHILD, M. F. Scale in GIS: An overview. Geomorphology, v. 130, p. 5-9, 2011.

GORI, Y.; STRADIOTTI, A.; CAMIN, F. Timber isoscapes. A case study in a mountain area in the Italian Alps. Plos One, v. 13, n. 2, p. 1-22, 2018.

GRAGNANI, J. G.; GARAVELlO, M. E. P. E.; SILVA, R. J.; NARDOTO, G. B.; MARTINELLI, L. A. Can stable isotope analysis reveal dietary differences among groups with distinct income levels in the city of Piracicaba (southeast region, Brazil)? Journal of Human Nutrition and Dietetics, v. 27, n. 3, p. 270-279, 2014. http://dx.doi.org/10.1111/jhn.12148

GUTIÉRREZ-EXPÓSITO, C.; RAMÍREZ, F.; AFÁN, I.; FORERO, M. G.; HOBSON, K. A. Toward a deuterium feather isoscape for sub-Saharan Africa: Progress, challenges and the path ahead. PLoS One, v. 10, n. 9, p. 1-12, 2015. http://dx.doi.org/10.1371/journal.pone.0135938 
HARDT, F. A. S.; CREMER, M. J.; TONELLO JUNIOR, A. J.; BELLANTE, A.; BUFFA, G.; BUSCAINO, G.; MAZZOLA, S.; BARRETO, A. S.; MARTINELLI, L. A.; ZUPPI, G. M. Use of carbon and nitrogen stable isotopes to study the feeding ecology of small coastal cetacean populations in southern Brazil. Biota Neotropica, v. 13, n. 4, p. 90-98, 2013. http://dx.doi.org/10.1590/S1676-06032013000400009

HELLMANN, C.; GROBE-STOLTENBERG, A.; THIELE, J.; OLDELAND, J.; WERNER, C. Heterogeneous environments shape invader impacts: integrating environmental, structural and functional effects by isoscapes and remote sensing. Scientific Reports, v. 7, p. 1-11, 2017.

HELLMANN, C.; RASCHER, K. G.; OLDELAND, J.; WERNER, C. Isoscapes resolve species-specific spatial patterns in plant-plant interactions in an invaded Mediterranean dune ecosystem. Tree Physiology, v. 36, n. 12, p. 1460-1470, $2016 \mathrm{~b}$. http://dx.doi.org/10.1093/treephys/tpw075

HELLMANN, C.; WERNER, C.; OLDELAND, J. A spatially explicit dual-isotope approach to map regions of plant-plant interaction after exotic plant invasion. PLoS One, v. 11, n. 7, p. 1-16, 2016a. http://dx.doi.org/10.1111/j.1461-0248.2012.01761.x

HÉNAUX, V.; POWELL, L. A.; HOBSON, K. A.; NIELSEN, C. K.; LARUE, M. A. Tracking large carnivore dispersal using isotopic clues in claws: an application to cougars across the Great Plains. Methods in Ecology and Evolution, v. 2, n. 5, p. 489-499, 2011. http://dx.doi.org/10.1111/j.2041-210X.2011.00107.x

HILTON, R. G.; GALY, A.; WEST, A. J.; HOVIUS, N.; ROBERTS, G. G. Geomorphic control on the $\delta^{15} \mathrm{~N}$ of mountain forests. Biogeosciences, v. 10, n. 3, p. 1693-1705, 2013. http://dx.doi.org/10.5194/bg-10-1693-2013

HOBSON, K. A.; BARNET-JOHNSON, R.; CERLING, T. 2010. Using isoscapes to track animal migration. In: Isoscapes: Understanding movement, pattern, and process on earth through isotope mapping. Netherlands: Springer, p. 273-298, 2010. http://dx.doi.org/10.1007/978-90-481-3354-3_13

HOBSON, K. A.; DOWARD, K.; KARDYNAL, K. J.; MCNEIL, J. N. Inferring origins of migrating insects using isoscapes: a case study using the true armyworm, Mythimna unipuncta, in North America. Ecological Entomology, v. 43, n. 3, p. 332-341, 2018. http://dx.doi.org/10.1111/een.12505

HOBSON, K. A.; KARDYNAL, K. J. An isotope $\left(\delta^{34} \mathrm{~S}\right)$ filter and geolocator results constrain a dual feather isoscape $\left(\delta^{2} \mathrm{H}, \delta^{13} \mathrm{C}\right)$ to identify the wintering grounds of North American Barn Swallows. The Auk: Ornithological Advances, v. 133, n. 1, p. 86-98, 2016. http://dx.doi.org/10.1642/AUK-15-149.1

HOBSON, K. A.; VAN WILGENBURG, S. L.; LARSON, K.; WASSENAAR, L. I. A feather hydrogen isoscape for Mexico. Journal of Geochemical Exploration, v. 102, n. 3, p. 167-174, 2009. http://dx.doi.org/10.1016/j.gexplo.2009.02.002

HOBSON, K. A.; VAN WILGENBURG, S. L.; WASSENAAR, L. I.; POWELL, R. L.; STILL, C. J.; CRAINE, J. M. A multi-isotope $\left(\delta^{13} \mathrm{C}, \delta^{15} \mathrm{~N}, \delta^{2} \mathrm{H}\right)$ feather isoscape to assign Afrotropical migrant birds to origins. Ecosphere, v. 3, n. 5, p. 1-20, 2012b. http://dx.doi.org/10.1890/ES12-00018.1 
HOBSON, K.A.; VAN WILGENBUG, S. L.; WASSENAR, L.I.; LARSON, K. Linking hydrogen $(\mathrm{d} 2 \mathrm{H})$ isoscapes in feathers and precipitation: sources of variance and consequences for assignment to isoscapes. PLoS One, v. 7, n. 4, e35137, 2012a. http://dx.doi.org/10.1371/journal.pone.0035137

HOULTON, B. Z.; MARKLEIN, A. R.; BAI, E. Representation of nitrogen in climate change forecasts. Nature Climate Change, vol. v. 5, p. 398-401, 2015. http://dx.doi.org/10.1038/nclimate2538

IAEA/WMO. Global Network of Isotopes in Precipitation. The GNIP Database. Vienna: International Atomic Energy Agency, 2015.

JACKSON, P. C.; MEINZER, F. C.; BUSTAMANTE, M.; GOLDSTEIN, G.; FRANCO, A.; RUNDEL, P. W.; CALDAS, L.; IGLER, E.; CAUSIN, F. Partitioning of soil water among tree species in a Brazilian Cerrado ecosystem. Tree Physiology, v. 19, n. 11, p. 717-724, 1999. http://dx.doi.org/10.1093/treephys/19.11.717

JASECHKO, S.; SHARP, Z. D.; GIBSON, J. J.; BIRKS, S. J.; YI, Y.; FAWCETT, P. J. Terrestrial water fluxes dominated by transpiration. Nature, v. 496, p. 347-350, 2013.

KERN, Z.; KOHÁN, B.; LEUENBERGER, M. Precipitation isoscape of high reliefs: Interpolation scheme designed and tested for monthly resolved precipitation oxygen isotope records of an Alpine domain. Atmospheric Chemistry and Physics, v. 14, n. 4, p. 1897-1907, 2014. http://dx.doi.org/10.5194/acp-14-1897-2014

LINS, S. R. M.; COLETTA, L. D.; RAVAGNANI, E. C.; GRAGNANI, J. G.; MAZZI, E. A.; MARTINELLI, L. A. Stable carbon composition of vegetation and soils across an altitudinal range in the coastal Atlantic Forest of Brazil. Trees, v. 30, n. 4, p. 1315-1329, 2016. http://dx.doi.org/10.1007/s00468-016-1368-7

LIU, Z.; BOWEN, G. J.; WELKER, J. M. Atmospheric circulation in reflected in precipitation isotope gradients over the conterminous United States. Journal of Geophysical Research, v. 115, D22120, 2010. http://dx.doi.org/10.1029/2010JD014175

LLOYD, J.; FARQUHAR, G. D. ${ }^{13} \mathrm{C}$ discrimination during $\mathrm{CO}_{2}$ assimilation by the terrestrial biosphere. Oecologia, v. 99, p. 201-215, 1994. http://dx.doi.org/10.1007/BF00627732

MALlETTE, J. R.; CASAlE, J. F.; JORDAN, J.; MORELlO, D. R.; BEYER, P. M. Geographically sourcing cocaine's origin - Delineation of the nineteen major cocoa growing regions in South America. Scientific Reports, v. 6, p. 1-10, 2016. http://dx.doi.org/10.1038/srep23520

MARDEGAN, S. F.; ANDRADE, T. M. B.; SOUSA NETO, E. R.; VASCONCELLOS, E. B. C.; MARTINS, L. F. B.; MENDONÇA, T. G.; MARTINELLI, L. A. Stable carbon isotope composition of Brazilian beers - A comparison between large- and small-scale breweries. Journal of Food Composition and Analysis, v. 29, n. 1, p. 52-57, 2013. http://dx.doi.org/10.1016/j.jfca.2012.10.004

MARTINELLI, L. A.; GAT, J. R.; CAMARGO, P. B.; LARA, L. L.; OMETTO, J. P. H. B. The Piracicaba River basin: isotope hydrology of a tropical river basin under anthropogenic stress. Isotopes in Environmental and Health Studies, v. 40, n. 1, p. 45 56, 2004. http://dx.doi.org/10.1080/10256010310001652016 
MARTINELLI, L. A.; MOREIRA, M. Z.; OMETTO, J. P. H. B.; ALCARDE, A. R.; RIZZON, L. A.; STANGE, E.; EHLERINGER, J. R. Stable carbon isotopic composition of the wine and $\mathrm{CO}_{2}$ bubbles of sparkling wines: detecting $\mathrm{C}_{4}$ sugar additions. Journal of Agricultural and Food Chemistry, v. 51, n. 9, p. 2625-2631, 2003. http://dx.doi.org/10.1021/jf026088c

MARTINELLI, L. A.; PICCOLO, M. C.; TOWSAND, A. R.; VITOUSEK, P. M.; CUEVAS, E.; MCDOWELL, W.; ROBERTSON, G. P.; SANTOS, O. C.; TRESEDER, K. Nitrogen stable isotopic composition of leaves and soil: Tropical versus temperate forests. Biogeochemistry, v. 46, n. 1, p. 45-65, 1999. http://dx.doi.org/10.1023/A:1006100128782

MEIER-AUGENSTEIN, W.; HOBSON, K.A.; WASSENAR, L.I. Critique: measuring hydrogen stable isotope abundance of proteins to infer origins of wildlife, food and people. Bioanalysis, v. 5, n. 7, p. 751-767, 2013. http://dx.doi.org/10.4155/bio.13.36

MORAiS, M. C.; PELlegrinetTI, T. A.; STURION, L. C.; SATTOlO, T. M. S.; MARTINELLI, L. A. Stable carbon isotopic composition indicates large presence of maize in Brazilian soy sauces (shoyu). Journal of Food Composition and Analysis, v. 70, p. 18-21, 2018. https://doi.org/10.1016/j.jfca.2018.04.001

MOREIRA, M. Z.; STERNBERG, L. S. L.; MARTINELLI, L. A.; VICTORIA, R. L.; BARBOSA, E. M.; BONATES, L. C. M.; NEPSTAD, D. C. Contribution of transpiration to forest ambient vapour based on isotopic measurements. Global Change Biology, v. 3, n. 5, p. 439-450, 1997. http://dx.doi.org/10.1046/j.1365-2486.1997.00082.x

MUELlER, M. H.; ALAOUI, A.; KUELLS, C.; LEISTERT, H.; MEUSBURGER, K.; STUMPP, C.; WEILER, M.; ALEWELL, C. Tracking water pathways in steep hillslopes by $\delta^{18} \mathrm{O}$ depth profiles of soil water. Journal of Hydrology, v. 519, p. 340-352, 2014. http://dx.doi.org/ 10.1016/j.jhydrol.2014.07.031

MURPHY, B.P.; BOWMAN, D. The carbon and nitrogen isotope composition of Australian grasses in relation to climate. Functional Ecology, v. 23, p. 1040-1049, 2009. http://dx.doi.org/10.1111/j.1365-2435.2009.01576.x

NARDOTO, G. B.; MURRIETA, R. S. S.; PRATES, L. E. G.; ADAMS, C.; GARAVELLO, M. E. P. E.; SCHOR, T.; MORAES, A.; RINALDI, F. D.; GRAGNANI, J. G.; MOURA, E. A. F.; DUARTE-NETO, P. J.; MARTINELLI, L. A. Frozen chicken for wild fish: Nutritional transition in the Brazilian Amazon region determined by carbon and nitrogen stable isotope ratios in fingernails. American Journal of Human Biology, v. 23, p. 642650, 2011. http://dx.doi.org/10.1002/ajhb.21192

NARDOTO, G. B.; OMETTO, J. P. H. B.; EHLERINGER, J. R.; HIGUCHI, N.; BUSTAMANTE, M. M. C.; MARTINELLI, L. A. Understanding the influences of spatial patterns on $\mathrm{N}$ availability within the Brazilian Amazon Forest. Ecosystems, v. 11, n. 8, p. 1234-1246, 2008. http://dx.doi.org/10.1007/s10021-008-9189-1

NARDOTO, G. B.; QUESADA, C. A.; PATIÑO, S.; SAIZ, G.; BAKER, T. R.; SCHWARZ, M.; SCHRODT, F.; FELDPAUSCH, T. R.; DOMINGUES, T. F.; MARIMON, B. S.; MARIMON, JUNIOR, B. H.; VIEIRA, I. C. G.; SILVEIRA, M.; BIRD, M. I.; PHILLIPS, O. L.; LLOYD, J.; MARTINELLI, L. A. Basin-wide variations in Amazon forest nitrogen-cycling characteristics as inferred from plant and soil ${ }^{15} \mathrm{~N}:{ }^{14} \mathrm{~N}$ measurements.

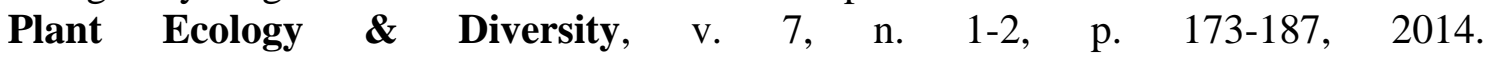
http://dx.doi.org/10.1080/17550874.2013.807524 
NARDOTO, G. B.; SILVA, S.; KENDALL, C.; EHLERINGER, J. R.; CHESSON, L. A.; FERRAZ, E. S. B.; MOREIRA, M. Z.; OMETTO, J. P. H. B.; MARTINELLI, L. A. Geographical patterns of human diet derived from stable-isotope analysis of fingernails. American Journal of Physical Anthropology, v. 131, n. 1, p. 137-146, 2006. http://dx.doi.org/10.1002/ajpa.20409

NIELSEN, J. A.; FREW, R. D.; WHIGHAM, P. A.; CALLAWAY, R. M.; DICKINSON, K. J. M. Thyme travels: ${ }^{15} \mathrm{~N}$ isoscapes of Thymus vulgaris $L$. invasion in lightly grazed pastoral communities. Austral Ecology, v. 41, n. 1, p. 28-39, 2016. http://dx.doi.org/10.1111/aec.12284

NITZSCHE, K. N.; VERCH, G.; PREMKE, K.; GESSLER, A.; KAYLER, Z. E. Visualizing land-use and management complexity within biogeochemical cycles of an agricultural landscape. Ecosphere, v. 7, n. 5, p. 1-16, 2016. http://dx.doi.org/10.1002/ecs2.1282

OLIVER, M. A.; WEBSTER, R. A tutorial guide to geostatistics: Computing and modelling variograms and kriging. Catena, v. 113, p. 56-69, 2014. http://dx.doi.org/10.1016/j.catena.2013.09.006

OMETTO, J. P. H. B.; EHLERINGER, J. R.; DOMINGUES, T. F.; BERRY, J. A.; ISHIDA, F. Y.; MAZZI, E.; HIGUCHI, N.; FLANAGAN, L. B.; NARDOTO, G. B.; MARTINELLI, L. A. The stable carbon and nitrogen isotopic composition of vegetation in tropical forests of the Amazon Basin, Brazil. Biogeochemistry, v. 79, p. 251-274, 2006. http://dx.doi.org/10.1007/s10533-006-9008-8

OMETTO, J. P. H. B.; FLANAGAN, L. B.; MARTINELli, L. A.; EHLERINGER, J. R. Oxygen isotope ratios of waters and respired $\mathrm{CO}_{2}$ in Amazonian forest and pasture ecosystem. Ecological Applications, v. 15, n. 1, p. 58-70, 2005. http://dx.doi.org/10.1890/03-5047

OMETTO, J. P. H. B.; FlANAGAN, L. B.; MARTINELli, L. A.; MOREIRA, M. Z.; HIGUCHI, N.; EHLERINGER, J. R. Carbon isotope discrimination in forest and pasture ecosystems of the Amazon Basin, Brazil. Global Biogeochemical Cycles, v. 16, n. 4, p. 1-10, 2002. http://dx.doi.org/10.1029/2001GB001462

ORCHARD, K. A.; CERnUSAK, L. A.; HUTLEY, L. B. Photosynthesis and water-use efficiency of seedlings from northern Australian monsoon forest, savanna, and swamp habitats grown in a common garden. Functional Plant Biology, v. 37, p. 1050-1060, 2010. http://dx.doi.org/10.1071/FP09306

PAULI, J. N.; NEWSOME, S. D.; COOK. J. A.; HARROD, C.; SHAWN, S. A.; BAKER, C. J. O.; BEN-DAVID, M.; BLOOM, D.; BOWEN, G. J.; CERLING, T. E.; CICERO, C.; COOK, C. DOHM, M.; DAHRAMPAL, P. S.; GRAVES, G.; GROPP, R.; HOBSON, K. A.; JORDAN, C.; MACFADDEN, B.; BIRCH, S. P.; POELEN, J.; RATNASIGHAM, S.; ROSSEL, L.; STRICKER, C. A.; UHEN, M. D.; YARNES, C. T.; HAYDEN, B. Why we need a centralized repository for isotopic data. PNAS, v. 114, n. 12, p. 2997-3001, 2017. http://dx.doi.org/10.1073/pnas.1701742114

PARDO, L. H.; NADELHOFFER, K. J. Using nitrogen isotope ratios to assess terrestrial ecosystems at regional and global scales. In: Isoscapes: Understanding movement, pattern, and process on earth through isotope mapping. Netherlands: Springer, p. 212250, 2010. 
PEEVA, A. IAEA Helps Brazil Strengthen Isotope Monitoring of Precipitation. Available in: https://www.iaea.org/newscenter/news/iaea-helps-brazil-strengthen-isotopemonitoring-of-precipitation. Access: Dec. 2018.

PÉREZ, T.; GARCIA-MONTIEL, D.; TRUMBORE, S.; TYLER, S.; CAMARGO, P. B.; MOREIRA, M.; PICCOLO, M.; CERRI, C. Nitrous oxide nitrification and denitrification ${ }^{15} \mathrm{~N}$ enrichment factors from amazon forest soils. Ecological Applications, v. 16, n. 6, p. 2153-2167, 2006. http://dx.doi.org/10.1890/1051-0761(2006)016[2153:NONADN]2.0.CO

POWELL, R. L.; YOO, E. H.; STILL, C. J. Vegetation and soil carbon-13 isoscapes for South America: integrating remote sensing and ecosystem isotope measurements. Ecosphere, v. 3, n. 11, p. 1-25, 2012. http://dx.doi.org/10.1890/ES12-00162.1

POWERS, J. S. Spatial variation of soil organic carbon concentrations and stable isotopic composition in 1-ha plots of forest and pasture in Costa Rica: Implications for the natural abundance technique. Biology and Fertility of Soils, v. 42, n. 6, p. 580-584, 2006. http://dx.doi.org/10.1007/s00374-005-0054-5

RASCHER, K. G.; HELlMANN, C.; MÁGUAS, C.; WERNER, C. Community scale ${ }^{15} \mathrm{~N}$ isoscapes: Tracing the spatial impact of an exotic $\mathrm{N}_{2}$-fixing invader. Ecology Letters, v. 15, n. 5, p. 484-491, 2012. http://dx.doi.org/10.1111/j.1461-0248.2012.01761.x

REED, E. T.; KARDYNAL, K. J.; HORROCKS, J. A.; HOBSON, K. A. Shorebird hunting in Barbados: Using stable isotopes to link the harvest at a migratory stopover site with sources of production. The Condor, v. 120, p. 357-370, 2018. http://dx.doi.org/10.1650/CONDOR-17-127.1

REGUEIRA, R. F. S.; BERNARD, E. Wildlife sinks: Quantifying the impact of illegal bird trade in street markets in Brazil. Biological Conservation, v. 149, n. 1, p. 16-22, 2012. http://dx.doi.org/10.1016/j.biocon.2012.02.009

RODRIGUES, L. P. F.; CARVALHO, R. C.; MACIEL, A.; OTANASIO, P. N.; GARAVELHO, M. E. P. E.; NARDOTO, G. B. Food insecurity in urban and rural areas in Central Brazil: Transition from locally produced foods to processed items. Ecology of Food and Nutrition, v. 55, n. 4, p. 365-377, 2016. http://dx.doi.org/10.1080/03670244.2016.1188090

RODRÍGUEZ-PÉREZ, M. Y.; AURIOLES-GAMBOA，D.; SÁNCHEZ-VELASCO， L.; LAVÍN, M. F.; NEWSOME, S. D. Identifying critical habitat of the endangered vaquita (Phocoena sinus) with regional $\delta^{13} \mathrm{C}$ and $\delta^{15} \mathrm{~N}$ isoscapes of the upper gulf of California, Mexico. Marine Mammal Science, v. 34, n. 3, 2018.

ROTH, F.; LESSA, G. C.; WILD, C.; KIKUCHI, R. K. P.; NAUMANN, M. S. Impact of a high-discharge submarine sewage outfall on water quality in the coastal zone of Salvador (Bahia, Brazil). Marine Pollution Bulletin, v. 106, p. 43-48, 2016. http://dx.doi.org/10.1016/j.marpolbul.2016.03.048

RUNDEL, C. W.; WUNDER, M. B.; ALVARADO, A. H.; RUEGG, K. C.; HARRIGAN, R.; SCHUH, A.; KELLY, J. F.; SIEGEL, R. B.; DESANTE, D. F.; SMITH, T. B.; NOVEMBRE, J. Novel statistical methods for integrating genetic and stable isotope data to infer individual-level migratory connectivity. Molecular Ecology, v. 22, n. 16, p. 4163-4176, 2013. http://dx.doi.org/10.1111/mec.12393 
SALEMI, L. F.; LINS, S. R. M.; RAVAGNANI, E. D. C.; FROSINI, S.; FERRAZ, D. B.; MARTINELLI, L. A. Past and present land use influences on tropical riparian zones: an isotopic assessment with implications for riparian forest width determination. Biota Neotropica, v. 16, n. 2, 2016. http://dx.doi.org/10.1590/1676-0611-BN-2015-0133

SALGADO, S. S.; MOTTA, P. C.; AGUIAR, L. M. S.; NARDOTO, G. B. Tracking dietary habits of cave arthropods associated with deposits of hematophagous bat guano: A study from a neotropical savanna. Austral Ecology, v. 39, n. 5, p. 560-566, 2014. http://dx.doi.org/10.1111/aec.12116

SANAIOTTI, T. M.; MARTINELLI, L. A.; VICTORIA, R. L.; TRUMBORE, S. E.; CAMARGO, P. B. Past vegetation changes in Amazon savannas determined using carbon isotopes of soil organic matter. Biotropica, v. 34, n. 1, p. 2-16, 2002. http://dx.doi.org/10.1111/j.1744-7429.2002.tb00237.x

SHIBUYA, E. K.; SARKIS, J. E. S.; NIGRINO-NETO, O.; OMETTO, J. P. H. B. Multivariate classification based on chemical and stable isotopic profiles in sourcing the origin of marijuana samples seized in Brazil. Journal of the Brazilian Chemical Society, v. 18, n. 1, p. 205-214, 2007. http://dx.doi.org/10.1590/S0103-50532007000100024

SHIBUYA, E. K.; SARKIS, J. E. S.; NIGRINO-NETO, O.; OMETTO, J. P. H. B. Multivariate classification based on chemical and stable isotopic profiles in sourcing the origin of marijuana samples seized in Brazil. Journal of the Brazilian Chemical Society, v. 18, n. 1, p. 205-214, 2007. http://dx.doi.org/10.1590/S0103-50532007000100024

SIQUEIRA, D. S.; MARQUES, J.; PEREIRA, G. T. The use of landforms to predict the variability of soil and orange attributes. Geoderma, v. 155, n. 1-2, p. 55-66, 2010. http://dx.doi.org/10.1016/j.geoderma.2009.11.024

SOLER I GIL, A.; BONOTTO, D. M. Hydrochemical and stable isotopes (H, O, S) signatures in deep groundwaters of Paraná basin, Brazil. Environmental Earth Sciences, v. 73, n. 1, p. 95-113, 2014. http://dx.doi.org/10.1007/s12665-014-3397-0

SOTO, D.X.; KOEHLER, G.; WASSENAR, L.I.; HOBSON, K.A. Re-evaluation of the hydrogen stable isotopic composition of keratin calibration standards for wildlife and forensic science applications. Rapid Communication in Mass Spectrometry, v. 31, n. 14, p. 1193-1203, 2017. http://dx.doi.org/10.1002/rcm.7893

STILL, C. J.; POWELL, R. L. Continental-scale distributions of vegetation stable carbon isotope ratios. In: Isoscapes: Understanding movement, pattern, and process on earth through isotope mapping. Netherlands: Springer, p. 179-194, 2010. http://dx.doi.org/10.1007/978-90-481-3354-3_9

SUITS N. S.; DENNING A. S.; BERRY J. A.; STILL C. J.; KADUK J.; MILLER J. B.; BAKER I. T. Simulation of carbon isotope discrimination of the terrestrial biosphere. Global Biogeochemical Cycles, v. 19, n. 1, p. 1-15, 2005. http://dx.doi.org/10.1029/2003GB002141

TEIXEIRA, F. C. P.; REINERT, F.; RUMJANEK, N. G.; BODDEY, R. M. Quantification of the contribution of biological nitrogen fixation to Cratylia mollis using the ${ }^{15} \mathrm{~N}$ natural abundance technique in the semi-arid Caatinga region of Brazil. Soil Biology and $\begin{array}{lllllll}\text { Biochemistry, } & \text { v. } \quad 38, \quad \text { n. } \quad 7, \quad \text { p. } & 1989-1993,\end{array}$ http://dx.doi.org/10.1016/j.soilbio.2005.11.013 
TERZER, S.; WASSENAAR, L. I.; ARAGUÁS-ARAGUÁS, L. J.; AGGARWAL, P. K. Global isoscapes for $\delta^{18} \mathrm{O}$ and $\delta^{2} \mathrm{H}$ in precipitation: Improved prediction using regionalized climatic regression models. Hydrology and Earth System Sciences, v. 17, n. 11, p. 4713-4728, 2013. http://dx.doi.org/10.5194/hess-17-4713-2013

VALENZUELA, L. O.; CHESSON, L. A.; O’GRADY, S. P.; CERLING, T. E.; EHLERINGER, J. R. Spatial distributions of carbon, nitrogen and sulfur isotope ratios in human hair across the central United States. Rapid Communications in Mass Spectrometry, v. 25, n. 7, p. 861-868, 2011. http://dx.doi.org/10.1002/rcm.4934

VANDER ZANDEN, H. B.; NELSON, D.; WUNDER, M. B.; CONKLING, T. J.; KATZNER, T. Application of isoscapes to determine geographic origin of terrestrial wildlife for conservation and management. Biological Conservation, v. 228, p. 268-280. 2018. https://doi.org/10.1016/j.biocon.2018.10.019

VANDER ZANDEN, H. B.; WUNDER, M. B.; HOBSON, K. A.; VAN WILGENBURG, S. L.; WASSENAAR, L. I.; WELKER, J. M.; BOWEN, G. J. Space-time tradeoffs in the development of precipitation-based isoscape models for determining migratory origin. Journal of Avian Biology, v. 46, n. 6, p. 658-667, 2015. http://dx.doi.org/10.1111/jav.00656

VIANI, R. A. G.; RODRIGUES, R. R.; DAWSON, T. E.; OLIVEIRA, R. S. Functional differences between woodland savannas and seasonally dry forests from south-eastern Brazil: Evidence from ${ }^{15} \mathrm{~N}$ natural abundance studies. Austral Ecology, v. 36, n. 8, p. 974-982, 2011. http://dx.doi.org/10.1111/j.1442-9993.2010.02233.x

VITÓRIA, A. P.; ÁVILA-LOVERA, E.; VIEIRA, T. O.; COUTO-SANTOS, A. P. L.; PEREIRA, T. J.; FUNCH, L. S.; FREITAS, L.; MIRANDA, L. D. P.; RODRIGUES, P. J. F. P.; REZENDE, C. E.; SANTIAGO, L. S. Isotopic composition of leaf carbon $\left(\delta^{13} \mathrm{C}\right)$ and nitrogen $\left(\delta^{15} \mathrm{~N}\right)$ of deciduous and evergreen understory trees in two tropical Brazilian Atlantic forests. Journal of Tropical Ecology, v. 34, n. 2, p. 145-156, 2018. http://dx.doi.org/10.1017/S0266467418000093

WANG, L.; OKIN, G. S.; D’ODORICO, P.; CAYLOR, K. K.; MACKO, S. A. Ecosystemscale spatial heterogeneity of stable isotopes of soil nitrogen in African savannas. Landscape Ecology, v. 28, p. 685-698, 2013

WARNER, M. M.; PLEMONS, A. M.; HEEMANN, N. P.; REGAN, L. A. Refining stable oxygen and hydrogen isoscapes for the identification of human remains in Mississippi. Journal of Forensic Sciences, v. 63, n. 2, p. 395-402, 2018.

WEINTRAUB, S. R.; COLE, R. J.; SCHMITT, C. G.; ALL, J. D. Climatic controls on the isotopic composition and availability of soil nitrogen across mountainous tropical forest. Ecosphere, v. 7, n. 8, p. 1-13, 2016. http://dx.doi.org/10.1002/ecs2.1412/supinfo

WEINTRAUB, S. R.; TAYLOR, P. G.; PORDER, S.; CLEVELAND, C. C.; ASNER, G. P.; TOWNSEND, A. R. Topographic controls on soil nitrogen availability in a lowland tropical forest. Ecology, v. 96, n. 6, p. 1561-1574, 2015. http://dx.doi.org/10.1890/140834.1

WEST, J. B.; BOWEN, G. J.; CERLING, T. E.; EHLERINGER, J. R. Stable isotope as one of nature's ecological recorders. Trends in Ecology \& Evolution, v. 21, n. 7, p. 408-414, 2006. http://dx.doi.org/ 10.1016/j.tree.2006.04.002 
WEST, J. B.; BOWEN, G. J.; DAWSON, T. E.; TU, K. P. Isoscapes: Understanding movement, pattern, and process on earth through isotope mapping. Netherlands: Springer, 2010 .

WEST, J. B.; SOBEK, A.; EHLERINGER, J. R. A simplified GIS approach to modeling global leaf water isoscapes. PLoS One, v. 3, n. 6, p. 1-8, 2008. http://dx.doi.org/10.1371/journal.pone.0002447

WUNDER, M. B. Determining geographic patterns of migration and dispersal using stable isotopes in keratins. Journal of Mammalogy, v. 93, n. 2, p. 360-367, 2012. http://dx.doi.org/10.1644/11-MAMM-S-182.1

WUNDER, M. B.; NORRIS, D. R. Improved estimates of certainty in stable-isotope-based methods for tracking migratory animals. Ecological Applications, v. 18, n. 2, p. 549-559, 2008 .

ZENNI, R. D.; ZILLER, S. R. An overview of invasive plants in Brazil. Revista Brasileira de Botânica, v. 34, n. 3, p. 431-446, 2011. http://dx.doi.org/10.1590/S010084042011000300016 